

\section{Editor's Introduction}

Welcome to the fourth issue of the biannual, peer reviewed, open access academic journal Philosophy of Coaching.

This is the first issue that has not been focused on a specific theme. Instead, in our Call for Papers we invited submissions on any and all topics relevant to the mission of the journal.

That mission, once again, is to:

- Initiate and sustain a rigorous, relevant inquiry into the nature and value of coaching

- Clarify assumptions embedded in the teaching and practice of coaching

- Critically examine and explore the implications of empirical research in the field

- Situate the field and the practice of coaching within a broader sociocultural and historical frame

- Explore the structure and impact of the institutions defining and governing the field

All the articles in this issue deliver fulsomely on that mission.

Tatiana Bachkirova and Simon Borrington's 'The Limits and Possibilities of a Person-Centered Approach In Coaching Through the Lens of Adult Development Theories' situates coaching against the backdrop of Carl Rogers' Person Centered Approach (PCA) to psychotherapy, asking when coaching aligned with PCA is appropriate and when it is less so. In answering this question she draws on a range of adult development theories, bringing them together under her own useful rubric of unformed, formed and reformed ego. The paper is helpful for anyone struggling to reconcile the different developmental theories, as well as practitioners looking to understand both the possibilities and limitations of different approaches to coaching, especially approaches aligned with PCA.

Michael Armour's paper, titled 'Supervision's "Three Amigos": Exploring the Evolving Functions of Supervision and its Application in the 
Field of Coaching,' focuses on the emerging field of coaching supervision in relation to its precursors in psychotherapy and social work. Amour asks, How are these professions different, and what are the consequences of those differences for supervision? In particular, given that coaching takes place in many different settings (including organizations) and has yet to find itself theoretically, how does coaching supervision need to be different to psychotherapy and social work supervision in terms of its core functions?

Dorrian Elizabeth Aiken and Salome Van Coller-Peter, in their article 'Developing Leaders at Business Schools with Coaching Skills Aligned with the Goals of Responsible Management Education,' take on the challenge of defining leadership development in business schools in line with the Principles for Responsible Management Education (PRME) and Sustainable Development Goals (SDGs) set out by the United Nations in 2015. Claiming that too often leadership development in organizations is delivered through off-site training that fails to deliver sustainable change, and drawing on their experience teaching the MPhil in Management Coaching at Stellenbosch Business School, they point to vertical development and the teaching of coaching skills in business schools as the key to developing leaders capable of improving the well-being for all earth's citizens.

Finally, Laura Lang's 'Coaching To What End? The Development and Enactment of a Shared Critically Oriented Coaching Discourse' focuses on literacy coaching in schools, and the value of co-creating a shared discourse among literacy coaches to support the social and political dimensions of their work. Lang's paper provides an example of how coaches can come together to develop a unique perspective, captured in a discourse, that is then capable of impacting the larger culture within which coaching takes place.

This issue of Philosophy of Coaching also includes two book reviews.

Elena Khomenko reviews The 9 Types of Leadership: Mastering the Art of People in the 21st Century Workplace by Beatrice Chestnut (2017), and Tamar Kagan reviews Who Do We Choose To Be?: Facing Reality, Claiming Leadership, Restoring Sanity by Margaret Wheatley (2017).

If you like what you read in these pages and would like to get involved, we are actively seeking the following: 
- Peer reviewers for future issues of the journal. If you are an expert in your field, please write to us and tell us what you're interested in reviewing.

- Writers for future issues of the journal. If you are a researcher, educator or coach practitioner, consider submitting your work for review and possible publication. Our most recent Call for Papers is on our website at philosophyofcoaching.org

- Suggestions for future themes. If there's a pressing question or concern you have about coaching as a field of inquiry or as a practice, send it along and we will try and turn it into a theme.

- Champions. Your colleagues can subscribe to the journal for free at philosophyofcoaching.org/subscribe.

You can always get in touch with me directly at julian@philosophyofcoaching.org.

I hope you enjoy this issue of the journal.

Julian Humphreys

Editor-in-Chief

Philosophy of Coaching: An International Journal 


\section{Editorial Board}

\section{Editor-in-Chief}

Julian Humphreys Ph.D.

\section{Senior Advisory}

Tatiana Bachkirova Ph.D. - Oxford Brookes University

Richard Boyatzis Ph.D. - Case Western Reserve University

Joan M. Batista Foguet Ph.D. - ESADE

Konstantin Korotov Ph.D. - ESMT Berlin

\section{Editorial Advisory}

Amanda Matejicek Ph.D.

Elizabeth McCourt J.D.

Evelina Rog Ph.D.

Jessica Sherin Ph.D., C.Psych

\section{Publishing Advisory}

Suzi Pomerantz - Library of Professional Coaching

Garry Schleifer - choice, the magazine of professional coaching

\section{Members}

Ann Betz

Vikki Brock Ph.D.

Daniel Doherty Ph.D.

Pauline Fatien Diochon Ph.D.

Judie Gannon Ph.D.

Tom Krapu Ph.D.

Leah Mazzola Ph.D.

Julie-Anne Tooth Ph.D.

Samuel Veissière Ph.D.

Tony Zampella 


\section{Table of Contents}

Editor's Introduction

$\begin{array}{ll}\text { Editorial Board } & 4\end{array}$

Table of Contents 5

The Limits and Possibilities of a Person-Centered Approach In Coaching Through the Lens of Adult Development Theories

$\begin{array}{ll}\text { Tatiana Bachkirova \& Simon Borrington } & 6\end{array}$

Supervision's 'Three Amigos': Exploring the Evolving Functions of Supervision and its Application in the Field of Coaching

Michael R. Armour

Developing Leaders at Business Schools with Coaching Skills Aligned with the Goals of Responsible Management Education

Dorrian Elizabeth Aiken \& Salome Van Coller-Peter

Coaching To What End? The Development and Enactment of a Shared Critically Oriented Coaching Discourse

Laura M. Lang

Book Review. The 9 Types of Leadership: Mastering the Art of People in the $21^{\text {st }}$

Century by Beatrice Chestnut

Reviewed by Elena Khomenko

Book Review. Who Do We Choose To Be?: Facing Reality, Claiming Leadership, Restoring Sanity by Margaret Wheatley

Reviewed by Tamar Kagan 


\title{
The Limits and Possibilities of a Person-Centered Approach In Coaching Through the Lens of Adult Development Theories
}

\author{
Tatiana Bachkirova \\ Oxford, UK
Simon Borrington
Oxford, UK

\begin{abstract}
The person-centred approach is one of the most recognised and respected theoretical positions amongst coaches because coaching shares a number of fundamental principles with this approach, such as the centrality of clients' experiences and the commitment to the idea that the client already is in possession of their own resources for growth. However, deviations from orthodox personcentred practices commonly occur even when it is being claimed as the primary theoretical approach. In this paper we offer a potential explanation for how such discrepancies between the rationale for practice and the practice itself occur from the perspective of adult development theories. Distinguishing person-centred 'philosophical attitude,' with its wide general appeal, from the unique and integrated approach to practice developed from the work of Carl Rogers, we suggest that the latter can further benefit and be enhanced by insights provided by adult development theories.
\end{abstract}

Keywords: person-centred approach, coaching, adult development theories, individual differences, philosophical pragmatism

\section{Introduction}

The person-centred approach (PCA) is well recognized as a basis for interventions not only in coaching but also in counselling, mentoring, social care, and teaching. The approach is grounded in a positive view of humanity that sees the person as innately striving towards becoming fully functioning. This 'actualizing tendency' (Rogers, 1951) can be blocked by a drive to act in ways that are consistent with a person's self-concept - the aspects of their personality which have been approved during the individual's development. However, if the practitioner provides an environment that is safe and nurturing the person can start to loosen their 'conditions of worth' and develop positive self-regard, self-trust and the ability to view the world more accurately. This

This is an Open Access article distributed under the terms of the Creative Commons Attribution (CC BY) License which permits use, distribution and reproduction in any medium, provided the original work is properly cited. 
approach minimises directive techniques, such as interpretation, questioning and collecting history, whilst also maximizing active listening, reflection of feelings and clarification. Rogers (1951) emphasises the attitudes and personal characteristics of the practitioner and the quality of the relationship as the prime determinant of the outcomes. It is not surprising from this description that this approach appeals to many practitioners. After all this time, since first being proposed by Rogers (1951), it stills speaks to the hearts of those whose genuine wish is for others to flourish.

From our experience of teaching different models to various coaching practitioners, we find that they often demonstrate a preference for personcentred theory as the one that resonates more than others. Firstly, it accords with the commonly held assumption that coaching clients are resourceful and capable (e.g. Rogers, 2012; Van Nieuwerburgh, 2017). Secondly, focusing on the experiences of the client and being led by the client's agenda is a central tenet of coaching practice (e.g. Stout Rostron, 2009; Wilson, 2007). Thirdly, the quality of the relationship between coach and client is considered the most important factor in the outcomes of coaching (e.g. De Haan \& Gannon, 2017; Palmer and McDowall, 2010). It is hardly surprising, then, that novice coaches often comment on how the theoretical foundation of the person-centred approach is clear, convincing and elegant. For the same reasons, many highly experienced coaches tend also to describe themselves as primarily personcentred practitioners (Joseph, 2014; Palmer and Whybrow, 2006).

As promising as this picture may look, however, the reality in practical application is not so straightforward. Although many practitioners often say that the person-centred approach provides the fundamental attitude to their practice, when asked what they do it appears that their actual practice takes many different shapes and forms that would not be automatically recognisable as conforming to the established criteria and expectations of "personcenteredness.' This perhaps stems from the potentially misleading presentation of PCA as a "way [that] allows for quick rapport and accurate assessment of the coaching situation" (Hedman, 2001, p. 76). In executive coaching, in particular, PCA is not generally presented as a robust 'standalone' theory - a place to begin, perhaps, but not to remain as the coaching relationship progresses, as it disregards too many other useful approaches and interventions (Peltier, 2001).

It appears, therefore, that although the principles of PCA in coaching are often readily assumed, the practice that then follows may deviate considerably from these principles. Joseph (2014) goes as far as to suggest that "as long as it is the coachee who is driving the session, the person-centred coach can draw on 
and offer to the coachee various exercises or techniques that may be drawn from cognitive behavioural, multimodal, solution-focused and systems theory" (p. 69). Such a wide interpretation of the person-centred approach seems to be removing the uniqueness of principled non-directivity that is integral to it. It becomes descriptive of a general interpersonal attitude of the coach to their client (and, indeed, to people in general), with an appreciation of the quality of the supportive relationship - "a philosophical approach to human relationship not a set of techniques" (Joseph, 2014, p. 71). This attitude is naturally compatible with any type and style of practice and not a particularly controversial position to hold as nearly any approach could claim commitment to the agenda of the client and importance of the supportive relationship. It seems a useful but watered-down version of Rogers' ideas in application for coaching practice. We believe that this distracts practitioners from understanding and utilising PCA as an integrated approach that combines an established theoretical framework with a well-tuned methodology for practice, falling to recognise that this integrated and fully-fledged PCA can be valuable for clients exactly because of the uniqueness of this approach.

The question remains, however, why practitioners deviate from the PCA as an integrated approach whilst continuing to subscribe to its principles and even feeling strongly committed to them. Some obvious explanations for this are that PCA as an integrated approach is too difficult for practitioners (Cooke, 2011), or that it does not work all the time (Peltier, 2001), or that there are some clients for whom it does not work at all (Corey, 2009). Although the first two reasons might have some merit, for the purposes of this paper we would like to concentrate on the third one. It is with appreciation of the range of individual differences that we wish to explore an extra dimension of these differences that might shed some new light on the most and least suitable clientele for PCA in coaching. Looking at it in this light may also have some practical application for other types of supportive relationships.

The dimension of individual differences that we wish to consider is not the one that is generally familiar to coaches and focuses on characteristics identified using various psychometric instruments. This less familiar dimension has been described by Cook-Greuter (2004) as 'vertical' in comparison to the commonly used 'horizontal' and is to be found in patterns described in adult development models by such theorists as Loevinger (1976) and Kegan (1982). Although the coaching community has embraced adult development theories more willingly than other supportive professional relationships, this approach continues to be somewhat marginalised in both academia and practice (Reams, 2016). However, we believe that adult 
development theories have the potential to add new insights into where, when and why PCA is the most effective interpersonal strategy, and those occasions when its suitability might be compromised.

\section{Theories of adult development}

Theories concerning the psychological development of adults (e.g. Kolhberg 1969; Loevinger, 1987; Perry, 1970; Kegan, 1982; Cook-Greuter, 1999 ) interest us in relation to the above challenges to PCA because we believe these theories shed further light on our understanding of individual differences. Many of these theories are conceived in the tradition of developmental structuralism, looking for patterns that connect specific psychological phenomena. These patterns suggest that people differ not only from each other in terms of personality types, learning styles and personal preferences, for example, but also provide insight as to how an individual becomes significantly different from the way they used to be in terms of how they make meaning of their experiences, reason about their values and act in the world. In addition to identifying certain patterns in the above changes, common to all people, theories of adult development suggest that changes occur in sequential stages through which people progress. The pace of such development is highly individual occurring naturally as the result of engagement with life tasks but can also be influenced by appropriate support and challenge that arise from supportive relationships such as coaching or counselling (Bachkirova, 2014).

Table 1 describes a simple three-stage framework for adult development in relation to specific psychological aspects as the most characteristic for the majority of adults (Beck \& Cowan, 1998; Wilber, 2000; Torbert, 1991) and arguably most typical for the clientele of coaches. The choice of aspects (e.g. cognitive style, ego development) is determined as being most descriptive according to Loevinger $(1976,1987)$. The main input for each of these aspects is drawn from the theories of Kegan (1982, 1994), Graves (1970), Torbert (1991), and Cook-Greuter (1999, 2004), with the use of another simplifying meta-perspective on these theories offered by McCauley et al. (2006). An additional aspect of 'engagement in action' is proposed by Bachkirova (2011, 2016a).

The overarching categories of the three groups described are named according to Bachkirova's (2011) distinction of unformed, formed and reformed ego. The term 'ego' is used to indicate the agency of the whole organism (its capacity to act in response to internal or external stimuli). A sign of a fully formed ego is the capacity of the organism to take ownership of past 
actions, withstand anxiety about what the future holds, and to possess the ability to build relationships with others without losing the sense of who they are (Bachkirova, 2011).

\begin{tabular}{|c|c|c|c|}
\hline Stages & Unformed ego & Formed ego & Reformed ego \\
\hline $\begin{array}{l}\text { Cognitive style } \\
\text { (mostly Kegan } \\
\text { 1982) }\end{array}$ & $\begin{array}{l}\text { Socialised mind } \\
\text { Ability for abstract } \\
\text { thinking and self- } \\
\text { reflection }\end{array}$ & $\begin{array}{l}\text { Self-authoring } \\
\text { mind } \\
\text { Can see } \\
\text { multiplicity and } \\
\text { patterns; critical } \\
\text { and analytical }\end{array}$ & $\begin{array}{l}\text { Self-transforming } \\
\text { mind } \\
\text { Systems view; } \\
\text { tolerance of } \\
\text { ambiguity; change } \\
\text { from linear logic to } \\
\text { holistic understanding }\end{array}$ \\
\hline $\begin{array}{l}\text { Interpersonal } \\
\text { style } \\
\text { (Loevinger 1987; } \\
\text { Cook-Greuter } \\
\text { 1999) }\end{array}$ & $\begin{array}{l}\text { Dependent } \\
\text { Conformist/self- } \\
\text { conscious } \\
\text { Need for belonging; } \\
\text { socially expected } \\
\text { behaviour in } \\
\text { relationships; } \\
\text { peacemakers/keepers }\end{array}$ & $\begin{array}{l}\text { Independent } \\
\text { Conscientious/ } \\
\text { individualist } \\
\text { Separate but } \\
\text { responsible for } \\
\text { their own } \\
\text { choices; } \\
\text { communication } \\
\text { and individual } \\
\text { differences are } \\
\text { valued }\end{array}$ & $\begin{array}{l}\text { Inter-independent } \\
\text { Autonomous/ } \\
\text { Integrated } \\
\text { Take responsibility for } \\
\text { relationship; respect } \\
\text { autonomy of others; } \\
\text { tolerance of conflicts; } \\
\text { non-hostile humour }\end{array}$ \\
\hline $\begin{array}{l}\text { Conscious } \\
\text { preoccupations } \\
\text { (Graves 1970) }\end{array}$ & $\begin{array}{l}\text { Multiplistic } \\
\text { Social acceptance, } \\
\text { reputation, moral } \\
\text { 'shoulds and oughts' }\end{array}$ & $\begin{array}{l}\text { Relativistic/ } \\
\text { Individualistic } \\
\text { Achievement of } \\
\text { personal goals } \\
\text { according to } \\
\text { inner standards. }\end{array}$ & $\begin{array}{l}\text { Systemic/integrated } \\
\text { Individuality; self- } \\
\text { fulfillment; immediate } \\
\text { present; } \\
\text { understanding } \\
\text { conflicting needs }\end{array}$ \\
\hline $\begin{array}{l}\text { Character } \\
\text { development } \\
\text { (Loevinger 1987; } \\
\text { Cook-Greuter } \\
\text { 1999; Kolhberg } \\
\text { 1969) }\end{array}$ & $\begin{array}{l}\text { Rule-bound } \\
\text { 'Inappropriate' feelings } \\
\text { are denied or } \\
\text { repressed. Rules of } \\
\text { important others are } \\
\text { internalised and } \\
\text { obeyed. }\end{array}$ & $\begin{array}{l}\text { Conscientious } \\
\text { Self-reliant, } \\
\text { conscientious; } \\
\text { follow self- } \\
\text { evaluated rules; } \\
\text { judge themselves } \\
\text { and critical of } \\
\text { others }\end{array}$ & $\begin{array}{l}\text { Self-regulated } \\
\text { Behaviour is an } \\
\text { expression of own } \\
\text { moral principles. } \\
\text { Concerned with } \\
\text { conflicting roles, } \\
\text { duties, value systems. }\end{array}$ \\
\hline $\begin{array}{l}\text { Engagement in } \\
\text { action } \\
\text { (Bachkirova } \\
2011 \text { ) }\end{array}$ & $\begin{array}{l}\text { Unformed ego } \\
\text { Reduced sense of } \\
\text { control over themselves } \\
\text { and environment. } \\
\text { Higher dependency on } \\
\text { others for action. }\end{array}$ & $\begin{array}{l}\text { Formed ego } \\
\text { Capacity to take } \\
\text { ownership of the } \\
\text { past and act } \\
\text { independently. } \\
\text { 'Mind over body' } \\
\text { control of action. }\end{array}$ & $\begin{array}{l}\text { Reformed ego } \\
\text { Harmony between } \\
\text { mind and body in } \\
\text { action. Appreciation } \\
\text { of complexity in the } \\
\text { relationship between } \\
\text { self and environment. }\end{array}$ \\
\hline
\end{tabular}


Table 1 A cumulative description of the three stages in adult psychological development with additions (Bachkirova, 2016a, p.302)

It is important to note at this point that there are many controversies and misunderstandings in relation to adult development theories and their 'use' in coaching practice, including:

- concerns about oversimplifying linearity and unjustified generalisation in conceptualising individual development (Adam \& Fitch 1982; Westenberg \& Gjerde 1999; Manners \& Durkin 2001);

- implied judgment and over-categorising, particularly when the use of measurement instruments is involved (Bachkirova, 2011);

- overzealous calls for prescriptive assessment and matching of coaches and clients (Berger, 2006; Bachkirova \& Cox, 2007).

(for extensive critiques of these, and other aspects, see Bachkirova \& Cox, 2007; Bachkirova, 2014; Lawrence, 2017).

Our position is that adult development theories are not given sufficient attention as they fall into the 'no man's land' between the dominant modernist and postmodernist camps, and from there are subjected to severe, but possibly inconsistent, critique. For example, from the modernist perspective, methodologies for measuring stages of development are not sufficiently precise (requiring too high-level interpretation) to be considered as scientifically sound (McCauley et al. 2006; Manners \& Durkin 2001). As a consequence, the research based on these measures is seen as highly questionable (limited samples; lack of longitudinal studies; factors undermining quality of measurement, e.g. verbal fluency, educational and social background, level of IQ) (Adam \& Fitch 1982; Westenberg \& Gjerde 1999; Manners \& Durkin 2001). From the postmodernist position, the above concerns are less relevant in comparison to the violation of the principle of aperspectivism (Fishman, 1999). With this commitment to the equality of perspectives, any apparent hierarchies that are implied by developmental stages and the seemingly teleological nature of these theories are too big a challenge (Paulson, 2007).

Without setting out to respond to all of these critiques in attempting to not 'throw the baby out with the bath water,' we will briefly indicate how 'a third way' of philosophical pragmatism enables the possible option of keeping the ideas of adult development theories relevant to helping practices whilst utilising them for the purpose of exploring PCA. We will sketch our position through four points which we believe justify the validity of adult development theories 
in relation to helping practices, thereby hopefully addressing a number of concerns that may give rise to reservations about these theories.

1. All theories can be valid if they are useful according to the pragmatic principle of expediency (James, 2014). It can be argued that theories of adult development have passed the test of time so far. There is a growing body of research, both qualitative and quantitative, in support of these theories (e.g. Berger and Atkins, 2009; Manner et al., 2004; Reams, 2016). There are new ways of conceptualizing practice based on meaningful interpretation of psychological phenomena using the idea of adult development (Chandler \& Kram, 2005; Kegan \& Lahey, 2009; Berger, 2006; Bachkirova, 2011). Practitioners make adjustments in engagements with clients when clients demonstrate a different way of thinking, for example (Berger and Fitzgerald, 2002; Berger, 2012; Reams \& Reams, 2015; Lawrence \& Allen, 2018).

2. According to John Dewey's pragmatic account of learning and growth (1916), we conceptualise individual development not in a controversial teleological sense with a predetermined end state, but as a sociobiological drive to learn, which does not stop in adulthood, and which also corresponds to an actualising tendency (Rogers, 1951). Psychological development is open-ended with infinite unfolding potential in the same way as any learning process (Dewey, 1916). Psychological development is a natural process that happens in the life of the individual in response to living in and acting on this world. It is influenced by many internal and external factors and thus happens at a different pace for different people. As development is a natural process, the amplifiers of this process, such as people and events, are also natural.

3. Although some patterns of changes in various aspects of individual development can be identified (e.g. Table 1), specific stages are not fixed, and sequences are not linear but are contingent upon context, the nature of each psychological aspect, and upon individual circumstances. Rather than the 'ladder' model of development, we see development according to the 'onion' model (Laurence \& Moore, 2018). This model implies a non-substantial nature of the self (Bazzano, 2014) or a modular nature (Bachkirova, 2011) according to which various functional mini-selves are assembled when called upon by the tasks of the internal or external environment. Although qualitatively different new ways of meaning making and acting, for example, develop as new layers of the onion, all layers can be represented in different situations 
and contexts. Even if a more advanced level of meaning making is already available to the person, depending on the circumstances, a particular mini-self can act and become dominant from the earlier layer.

4. According to the above view on the self and development, we argue that although some sort of gauging of where an individual's 'centre of developmental gravity' might be is theoretically possible, measurement and precision in this task is not only incredibly difficult but also not necessary. Bachkirova (2011) proposed that the actual issues that clients bring for coaching are already an indication of this centre. The practitioner, as in PCA, can be led by the client, and their specific expressed and emergent needs form the developmental theme that becomes the focus of coaching. Table 2 gives an indication of the developmental themes that clients bring for coaching according to the three stages described in Table 1. These themes indicate the types of difficulties that clients experience and wish to overcome. Such classificatory markers should be viewed only as additional material for reflection that the practitioner may utilise in preparation for sessions and in supervision.

\begin{tabular}{|c|c|c|}
\hline Unformed ego & Formed ego & Reformed ego \\
\hline $\begin{array}{l}\text { Decision-making in difficult } \\
\text { situations with a number of } \\
\text { stake-holders } \\
\text { Taking higher level of } \\
\text { responsibility than they feel they } \\
\text { can cope with } \\
\text { Work-life balance connected to } \\
\text { inability to say 'no' } \\
\text { Performance anxiety } \\
\text { Issues of self-esteem }\end{array}$ & $\begin{array}{l}\text { Coping with high amount of } \\
\text { self-created work } \\
\text { Achievement of recognition, } \\
\text { promotion, etc. } \\
\text { Interpersonal conflicts } \\
\text { Problem solving } \\
\text { Learning to delegate } \\
\text { Stress management }\end{array}$ & $\begin{array}{l}\text { Dissatisfaction with life in spite } \\
\text { of achievements } \\
\text { Internal conflict } \\
\text { Not 'fitting in' } \\
\text { Search for meaning } \\
\text { Overcoming life crisis } \\
\text { Initiating a significant life } \\
\text { change } \\
\text { Staying true to themselves in a } \\
\text { complex situation }\end{array}$ \\
\hline
\end{tabular}

Table 2: Three groups of developmental themes (adapted from Bachkirova, 2013)

We hope that the above provides a brief framework for understanding adult development theories. We also believe that, in the context of philosophical pragmatism, adult development theories are not in conflict with 
the basic tenets of person-centred theory and reflect the influence that John Dewey had on Rogers' ideas concerning the inherent nature of the actualizing tendency (Rogers, 1951). Making such a case in support of adult development theories provides us with a lens through which PCA can be explored in a coaching context. It is possible that other helping practices may benefit from any insights arrived at in this way.

\section{Exploring the applicability of the Person-Centred Approach in light of theories of adult development}

As we already identified above, there is a clear difference between having a person-centred attitude and utilizing fully integrated PCA in practice. In this section we explore the use of PCA as a full methodology when working with clients from the three different stages of adult development. It is possible that the main strength of this approach is to be realised when used in working with clients who are situated at a particular developmental stage - a stage we have identified as that of 'unformed ego'. We would also suggest that PCA may have some limitations and may be ultimately ineffective when working with clients who are at the 'formed ego' and 'reformed ego' stages.

\section{Unformed ego}

The most characteristic feature of an individual at the developmental stage of 'unformed ego' is that of someone who is very unsure of their abilities in certain areas of their life and consequently in need of more guidance and support. This leads to a higher dependency on others, which can result in a reduced sense of control over their environment. The issues of confidence and self-esteem often become an overarching developmental theme for coaching people with an unformed ego, because their wellbeing depends on how they are seen, valued, and validated by others (Bachkirova, 2011). Kegan (1982) even suggests that, strictly speaking, 'self-esteem' is not an applicable term for individuals at this stage, as their 'esteem' does not come from their sense of 'self,' but rather from the received and unexamined opinions of others. In Maslow's hierarchy of needs (1954), self-esteem and belonging would be the corresponding stage for the unformed ego.

The value of PCA at this level of intervention comes with the provision of unconditional positive regard for these clients, irrespective of their actions, achievements, values or their stage of development. This is a most powerful supportive strategy for a client who is lacking in self-acceptance and, if it is offered together with other conditions typical to this approach, can allow the 
client to reclaim self-respect and to gain a deeper sense of their own needs and potential strengths (Joseph \& Bryant-Jefferies, 2007; Joseph, 2014).

It is noteworthy that, according to various researchers, this group of adults constitutes by far the most populated developmental stage in comparison to the other two (see Cook-Greuter, 2004). Even if the validity of these statistics can be challenged in terms of the proportion of a general population, anecdotal evidence from coaching practitioners and coaching supervisors tend to support this estimation in relation to coaching clients. However, coaches may not be confident enough, or misled by some literature (e.g. Peltier, 2001), to work with these clients using PCA as the sole methodology, 'uncontaminated' by other approaches. In our view they should be encouraged to do this without feeling obliged to bring any greater methodological diversity to their practice.

\section{Formed ego}

There is some anecdotal evidence arrived at from coaching supervisors that when PCA coaches work with clients who can be usefully identified as 'formed ego,' they may find themselves less equipped to deal with the client's needs. The need for acceptance by these clients is no longer an overriding concern. Clients at this stage are generally able to accept themselves and 'to stand on their own two feet.' They can differentiate themselves from their immediate contexts and express their individuality. They manage tasks that are important to them by relying on their own resources. They can reflect on their own qualities in a more detached way and may willingly face and even create challenges to test their ego.

These capabilities do not mean that these people are free from difficulty. Their choices may be constructive or destructive even if chosen according to their own criteria. The sense of control and self-ownership that they have developed may lead to an overestimation of what is possible and realistic for that individual. The sense of independence from other people may lead to conflicts in relationships or isolation. However, they will feel less like the victims of circumstance and some may even enjoy the emergent challenges. Therefore, they may experience the style of a PCA practitioner as insufficiently challenging. They may wish for a more open and intense engagement with the coach, not necessarily in a directive style but as being more actively involved in a dialogue with a greater degree of self-disclosure and even confrontation.

In coaching, and particularly in executive coaching, these clients do not constitute an unusual clientele even though this group is statistically smaller 
than the unformed ego group (Cook-Greuter, 2004), which might go some way in explaining the concerns expressed in coaching literature about the limitations of PCA. Therefore, we suggest that when dealing with clients from this developmental category, although a person-centred attitude is perfectly appropriate, it is justified to move beyond a strict adherence to a person-centred methodology and to draw upon other resources. It might explain why, on encountering this type of client, practitioners who are committed solely to PCA may find that they are insufficiently equipped.

\section{Reformed ego}

In regard to the third developmental category, the 'reformed ego,' PCA may be an effective methodology when these clients have an explicit need to process their developmental themes in their own way with the main relational requirement being the presence of a supportive listener. Such individuals are quite capable of self-developing. They already accept themselves and working with them would need more freedom and creativity than perhaps PCA as a methodology can offer. It would also need the overall capacity of the practitioner to resonate with these clients' meaning making system and therefore may require the practitioner themselves to be at a developmental stage that enables them to offer responses, where necessary, of sufficient depth.

The kinds of themes that reformed ego clients tend to want to address indicates that their capacity to act and reflect go beyond those of the two other groups. This capacity is determined by achieved ability to act efficiently, thus leaving more energy and attention available for the conscious awareness of the situations, the organism as a whole and the relationship between them (Bachkirova, 2011). This allows recognizing conflicts between their various sub-selves, nuances of contexts and limitations to the ways the situations are perceived and interpreted. These clients can be in control of the situation without the need to control everything, as they are better equipped to be able to tolerate the ambiguity of some needs and tasks. Instead of investing in being right and efficient, they become increasingly interested in being authentic and not engaging in self-deception. They can be insightful about their internal conflicts as well as being constructively critical about the state of affairs around them. As this group seems to be even smaller than that of the formed ego, they may suffer from a lack of understanding from and substantive connection with others.

Coaching relationships with these clients may come to a premature end when they recognise that a particular practitioner cannot offer more than these 
clients can already do by themselves. If the engagement is to continue it might become more developmental for the practitioner than for the client. Alternative approaches to PCA that may be more productive, such as Gestalt and Existential, have been recommended as being more stretching for these clients (Bachkirova, 2011). These methodologies may be more efficacious in tapping into 'the client's growth edge' (Berger, 2012, p. 94). However, we would argue that more than the methodological approach itself, it is the self of the practitioner that makes the key difference at this level of engagement. This might also hold to be the case in supportive relationships other than coaching.

\section{Conclusion}

In this paper, we have been using a lens of adult development theories to explore the applicability of PCA for different clientele of coaching with a view to offering an explanation for some potential limitations of this approach. We have been suggesting the need to expand the use of PCA for clients of 'unformed ego' stage and to consider other coaching approaches as better options than PCA for clients who are at developmental stages beyond 'unformed ego,' e.g., Solution-Focused approach for formed ego stage, and Gestalt and Existential approaches for reformed ego clients (Bachkirova, 2011).

Although we, hopefully, have already addressed some of the reservations that PCA practitioners outside of coaching might have in relation to these theories, there is yet another reservation that is left to discuss: the concern that theories of psychological development imply a judgement being made about some status level of another person. This would seem to clash with a commitment of the person-centred practitioner to the idea of coaching relationships as being fundamentally non-judgemental. We believe however that similar judgements are made on an everyday basis by all of us. What matters is the purpose of the judgement (or assessment) and its validity. It is more than possible in person-centred practice to assess where the client is in terms of their meaning making or engagement in action, whilst at the same time displaying unconditional acceptance and positive regard. Making a developmental assessment does not entail providing a 'complete' understanding of the client, but it can help the practitioner to listen in a better way to clients' concerns and to be more present in their search for a better fit between the context in which an individual's difficulty arises and their capacity for dealing with it (Kegan, 1994; Berger, 2012).

We also believe that being more developmentally minded or having at least a curiosity about psychological development in adulthood can be 
developmental for practitioners as it adds another dimension to the spectrum of psychological diversity they face in their work. It is important to emphasise yet again that the self of the practitioner, their attitude to change and human nature, their personal values and the way that they make meaning play very important roles in establishing the appropriate supportive relationship for the client in question. Theories of adult development have something important to say in this regard. Kegan (1994) argued that people feel 'in over their heads' in any work they do when the complexity of their job is greater than the capability of their meaning making system. In coaching practice this is also possible and probably most noticeable with approaches in which the practitioner cannot hide behind various techniques and interventions, PCA being one of these. Although we do not subscribe to the strong views of some coaching authors (e.g. Laske, 2006) who argue that the coach should know their stage and be at the same or higher stage of development as their client, we recognise the inherent complexity of the relationships showing a significant developmental mismatch between the coach and client.

This might require from the PCA practitioner a sensitivity and honesty in relation to the 'in over their head' phenomenon in relation to certain clients and further require them to consider referral to a colleague who might be more suitable for such a challenge. On the other hand, in recognising his or her own limitations the practitioner is provided with an incentive for continuing not only professional but also personal development (Bachkirova, 2016b). It has been argued (Cook-Greuter, 1999; Berger \& Fitzgerald, 2002) that each stage enriches individual capacity for reflection and for effective interaction with others and with tasks. The capacity to understand others and to notice nuances and details of situations increases with a better opportunity to articulate and potentially change these situations - all-important for the coaching practitioner.

\section{References}

Adams, G., \& Fitch, S. (1982). Ego stage and identity status development: A cross sequential analysis. Journal of Personality and Social Psychology, $43,574-583$.

Bachkirova, T. (2011). Developmental Coaching: Working with the Self. Maidenhead: Open University Press.

Bachkirova, T. (2013). Developmental coaching: Developing the self. In J. Passmore, D. Peterson, \& T. Freire (Eds.), The Wiley-Blackwell handbook of the psychology of coaching and mentoring (pp.135-154). Chichester: John Wiley and Sons Ltd. 
Bachkirova, T. (2014). Psychological Development in Adulthood and Coaching. In E. Cox, T. Bachkirova \& D. Clutterbuck (Eds.), The Complete Handbook of Coaching (2nd ed.) (pp. 131-144). London: Sage.

Bachkirova, T. (2016a). Developmental coaching: theory and practice. In R. Wegener, S. Deplazes, M. Hasenbein, H. Künzli, A. Ryter and B. Uebelhardt (Eds.), Coaching as an individual response to social developments (pp. 295-306). Wiesbaden: Springer VS Research.

Bachkirova, T. (2016b) The Self of the Coach: Conceptualization, Issues, and Opportunities for Practitioner Development. Consulting Psychology Journal: Practice and Research, 68(2), 143-156.

Bachkirova, T., \& Cox, E. (2007). A Cognitive Developmental Approach for Coach Development. In S. Palmer \& A. Whybrow (Eds.), Handbook of Coaching Psychology: A Guide for Practitioners (pp. 325-350). London: Routledge.

Bazzano, M. (2014). Togetherness: Intersubjectivity revisited. Person-Centred \& Experiential Psychotherapies, 13(3), 203-216.

Beck, D., \& Cowan, C. (1996). Spiral Dynamics. Oxford: Blackwell.

Berger, J. (2012). Changing on the Job: Developing Leaders for a Complex World. Stanford: Stanford Business Books.

Berger, J., \& Atkins, P. (2009). Mapping complexity of mind: using the subject-object interview in coaching. Coaching: An International Journal of Theory, Research and Practice, 2(1), 23-36.

Berger, J. (2006). Adult Development Theory and Executive Coaching Practice. In Stober D. \& Grant, A. (Eds.), Evidence Based Coaching Handbook: putting best practices to work for your clients (pp. 77-102). Chichester: John Wiley.

Berger, J., \& Fitzgerald, C. (2002). Leadership and Complexity of Mind: The Role of Executive Coaching. In C. Fitzgerald \& J. Berger (Eds.), Executive Coaching: Practices \& Perspectives (pp. 27-58). Palo Alto: Davies-Black Publishing.

Chandler, D. \& Krum, K. (2005). Applying an adult development perspective to developmental networks. Career Development International, 10(6/7), 548-566.

Cook-Greuter, S. (2004). Making the case for developmental perspective. Industrial and Commercial Training, 36(7), 275-281.

Cook-Greuter, S. (1999). Postautonomous ego development: Its nature and measurement. Unpublished doctoral thesis. Cambridge, MA: Harvard Graduate School of Education. 
Cooke, B. (2011). The person-centred approach in coaching supervision. In T. Bachkirova, P. Jackson \& D. Clutterbuck (Eds.), Coaching \& Mentoring Supervision: Theory and Practice (pp. 133-143). Maidenhead: Open University Press.

Corey, G. (2009). Theory and Practice of Counselling and Psychotherapy (8 ed.). Belmont: Thomson Brooks/Cole.

De Haan, E. \& Gannon, J. (2017). The Coaching Relationship. In T. Bachkirova, G. Spence \& D. Drake (Eds.), The SAGE Handbook of Coaching (pp. 195-217). London: Sage.

Dewey, J. (1916). Democracy and Education: An introduction to the philosophy of education. London: Macmillan.

Fishman, D. (1999). The Case for Pragmatic Psychology. New York: New York University Press.

Graves, C. (1970). Levels of Existence: An Open System Theory of Values. Journal of Humanistic Psychology, 10 (2), 131-155.

Hedman, A. (1999). The Person-Centered Approach. In B. Peltier (Ed.), The Psychology of Executive Coaching: Theory and Application (pp. 66-80). London: Routledge.

James, W. (2014). Lecture 6: Pragmatism's Conception of Truth. In D. Olin (Ed.) William James: Pragmatism, in focus (pp. 99-115). London: Routledge.

Joseph, S. \& Bryant-Jefferies, R. (2007). Person-centred coaching psychology. In S. Palmer and A. Whybrow (Eds.), Handbook of Coaching Psychology: A Guide for practitioners, (pp. 211-228). London: Routledge.

Joseph, S. (2014). The Person-Centred Approach to Coaching. In E. Cox, T. Bachkirova and D. Clutterbuck (Eds.), The Complete Handbook of Coaching (pp. 65-76). London: Sage.

Kegan, R. (1994). In Over Our Heads. London: Harvard University Press.

Kegan, R. (1982). The Evolving Self: Problem and Process in Human Development. London: Harvard University Press.

Kegan, R. \& Lahey, L. (2009). Immunity to Change: How to overcome it and unlock the potential in yourself and your organisation. Boston: Harvard Business Press.

Kohlberg, L. (1969). Stages in the development of moral thought and action. New York: Holt, Reinhart and Winston.

Laske, O. (2006). From coach training to coach education: Teaching coaching within a comprehensively evidence-based framework. International Journal of Evidence Based Coaching and Mentoring, 1(1), 45-57. 
Lawrence, P. (2017). Coaching and Adult Development. In T. Bachkirova, G. Spence \& D. Drake (Eds.), The SAGE Handbook of Coaching (pp. 121138). London: Sage.

Lawrence, P. \& Moore, A. (2018, in press). Coaching in Three Dimensions: Meeting the challenges of a complex world. London: Routledge.

Loevinger, J. (1976). Ego Development: conceptions and theories. San Francisco: Jossey-Bass.

Loevinger, J. (1987). Paradigms of Personality. New York: Freeman.

Manners, J., \& Durkin, K. (2001). A Critical Review of the Validity of Ego Development Theory and Its Measurement. Journal of Personality Assessment, 77(3), 541-567.

Manner, J., Durkin, K. \& Nesdale, A. (2004). Promoting Advanced Ego Development Among Adults. Journal of Adult Development, 11(1), pp. 1927.

McCauley, C., Drath, W., Palus, P., O'Connor, B. \& Baker, B. (2006). The use of constructive-developmental theory to advance the understanding of leadership. The Leadership Quarterly, 17, 634-653.

Maslow, A. (1954). Motivation and personality. New York: Harper.

Palmer, S. \& Whybrow, A. (2006). The coaching psychology movement and its development within the British Psychological Society. International Coaching Psychology Review, 1(1), 5-11.

Palmer, S. \& McDowall, A. (2010). The Coaching Relationship: Putting people first. London: Routledge.

Paulson, D. (2007). Wilber's integral philosophy: A summary and critique. Journal of Humanistic Psychology, 48(3), 364-388.

Perry, W.G. (1970). Forms of intellectual and ethical development in the college years. New York: Holt, Rinehart and Winston.

Peltier, B. (2001). The Psychology of Executive Coaching: Theory and application. London: Routledge.

Reams, J. (2016). An Overview of Adult Cognitive Development Research and Its Application in the Field of Leadership Studies. Behavioral Development Bulletin, 22(2), 334-348.

Reams, J. \& Reams, J. (2015). Awareness based technologies for leadership development: Utilising Immunity to Change Coaching. International Journal of Evidence Based Coaching and Mentoring, 13(2), 14-28.

Rogers, C. R. (1951). Client-centred therapy: Its current practice, implications and theory. Boston, MA: Houghton Mifflin.

Rogers, J. (2012). Coaching Skills: A Handbook ( $3^{\text {rd }}$ ed). Maidenhead: Open University Press. 
Stout Rostron, S. (2009). Business Coaching International: Transforming Individuals and Organizations. London: Karnac.

Torbert, W. (1991). The Power of Balance. Newbury Park: Sage.

Van Neeuwerburgh, C. (2017). An Introduction to coaching skills: A practical guide ( $2^{\text {nd }}$ ed.). London: Sage.

Wilson, C. (2007). Best practice in performance coaching: A Handbook for Leaders, Coaches, HR Professionals and Organizations. London: Kogan Page.

Westenberg, P., \& Gjede, P. (1999). Ego development during the transition from adolescence to young adulthood: A 9-year longitudinal study. Journal of Research in Personality, 33, 233-252.

Wilber, K. (2000). Integral Psychology. London: Shambala. 


\title{
Supervision's 'Three Amigos': Exploring the Evolving Functions of Supervision and its Application in the Field of Coaching
}

\author{
Michael R. Armour \\ Sydney, Australia
}

\begin{abstract}
The literature on supervision includes an enduring theme related to the 'functions' of supervision. However, each helping profession has defined the functions of supervision somewhat uniquely. Within the field of social work functions are defined as being "administrative, educational and supportive" (Kadushin, 1976, pp. 20-21), indicating specific roles that are undertaken by the agent-supervisor. The notion of functions also appears to have been widely embraced within counseling literature, although the terms have been adapted as a framework of tasks being "formative, restorative and normative" (Proctor, 2000, p. 12), to describe processes which are for the benefit of the therapist. More recently, the concept of functions has made its way into the discourse on coaching supervision, where the main functions have been defined as "qualitative, resourcing and developmental" (Hawkins \& Shohet, 2006, p. 57). Despite the use of these terms in different fields, there is little discussion on the extent to which these ideas have been adopted, and a lack of empirical research on the relevance and effectiveness of functions in relation to coaching supervision. This article explores the emergence of supervision functions, the context in which functions have been applied, and their translation from social work to therapy and more recently coaching. Further research is needed on the relevance and application of functions in the area of coaching supervision.
\end{abstract}

Keywords: Supervision functions, social work supervision, coaching supervision

\section{Introduction}

For over forty years, the concept of 'functions' has been a key theme in the literature on supervision. Dawson (1926) first described the educational, administrative and supportive functions of supervision, suggesting that supervision was as much a managerial process as "cultivating harmonious relationships and esprit de corps" (Dawson, 1926, p. 293). The term 'functions' has different meanings depending on the context in which supervision takes place. Within social work, Kadushin (1976) uses the term to describe the role of the supervisor in ensuring that charity organizations delivered an effective and efficient service, and that quality standards were

This is an Open Access article distributed under the terms of the Creative Commons Attribution (CC BY) License which permits use, distribution and reproduction in any medium, provided the original work is properly cited. 
being maintained by the untrained volunteer social workers or "visitors" (Kadushin, 1991a, p. 2). In the arena of counseling, Proctor (1994) uses 'functions' in terms of benefits to the supervisee indicating the importance of support and well-being. Having worked with both models, Hawkins \& Shohet (2006) developed their own model to focus on the process that takes place and the relationship between the supervisor and supervisee.

As the field of social work continued to develop in the late nineteenth and early twentieth century, Tsui (2008) noted that by the 1930s a closer integration was taking place between social work and psychoanalysis, with supervision becoming more of a therapeutic process or "casework for the caseworker" (Tsui, 2008, p. 193) rather than ensuring the efficiency of the agency. The psychoanalytic approach did not gain universal support among social workers, in part due to a concern over infringing on the autonomy of the social workers themselves and the nature of the social work profession where the focus of the agency's effort was to meet the immediate survival needs of their clients, in contrast to providing therapeutic outcomes (Tsui, 2008).

Hawkins and Shohet (1989) use their definition of functions in a broader framework of 'helping professions,' and two recent papers have explored 'developmental, resourcing and qualitative functions' specifically in the context of coaching supervision (Clutterbuck, Whitaker, \& Lucas, 2016a; Lucas \& Larcombe, 2016). While there is some overlap between social work and coaching in terms of the quality and development functions of supervision, further consideration needs to be given to the role of the coaching supervisor. Specific focus areas include quality assurance for organizational sponsors, development and support for the coaches, and enhancing the reputation of the coaching profession.

The goal of this paper is to trace the emergence of 'functions of supervision' in social work, therapy and coaching, to discuss the challenges and opportunities of functions in coaching supervision, and to comment on a possible integrated view of functions as proposed by Hawkins \& Shohet (2006).

\section{Emergence: functions in social work supervision}

The origins of social work date back to 1878 with the creation of the Charity Organization Movement (COM), which began in Buffalo, USA, in that same year (Tsui, 2008). The idea that supervision comprised three core functions emerged over many decades to ensure that agencies associated with the COM were providing an effective and efficient service to families in need, 
while supporting visitors who were the front-line workers of the specific agency. The 'visitor', an untrained volunteer, was required to work closely with the agent-supervisor, a paid role within the charity organization, to recommend what support the agency could offer families in need.

In its original conception, social work supervision was related to the "inspection and review of institutions rather than the support of individual workers" (Kadushin, 1991a, p. 1), suggesting an administrative, rather than educational or supportive, focus for the supervision process. However, from the very beginning of the COM, visitors were also provided with education and support through the offices of the "agent-supervisor" (Kadushin, 1991a, p. 10). This was essential in the early development of the social work profession, as "most of the agency visitors were untrained" (Tsui, 2008, p. 192). According to Tsui (2008), many of these volunteer visitors came from middle and upperclass backgrounds and were unprepared to deal with the poverty resulting from economic depression and hardship.

The role and tasks of the agent-supervisor continued to develop as the field of social work gained momentum. An initial six-week training program for social workers commenced in 1898, and the first course in supervision was offered in 1911 with the support of the Charity Organization's Department of the Russell Sage Foundation headed by Mary Richmond, one of the leading lights in development of social work practice (Kadushin, 1976; Munson, 2002a). And yet, "there were few or scattered references to supervision functions in the social work literature prior to 1920" (Kadushin, 1991b, p. 1).

The history of social work (Dan, 2017; Kadushin, 1991a; Munson, 2002b; Tsui, 2008) confirms growing ties between social workers and the psychoanalytic professions in the early twentieth century, and "the psychoanalytic treatment method was being widely used by caseworkers" (Tsui, 2008, p. 194). This approach, while still in use today, has been largely rejected by social workers who see the casework approach too closely aligned to the therapeutic model, as well as a potential "violation of the individual rights of the supervisees" (Tsui, 2008, p. 195). Munson (2002a) refers to social work moving back to its theoretical underpinning in social science, citing the work of Charlotte Towle who perceived the "process of supervision as consisting of three functions - administration, teaching and helping" (Perlman, 1969 , p. 266, as cited in Munson, 2002b, p. 64). While there remains considerable debate within the social work literature as to which of the functions is dominant, administrative or developmental (Tsui, 2008), to the dispassionate observer each of these functions appears to have taken precedence 
at a specific point in time to meet the changing needs of social workers and the social work profession.

The concept of functions appears to have found ready acceptance in the therapeutic context, although as will be seen in the following section, the focus of supervision was for the benefit of the therapist rather than the administration of the agency.

\section{Expansion: Functions in counseling and therapy}

Acknowledging the many distinctions within the psychoanalytic and psychological professions, Hawkins and Shohet (2006) coined the term 'helping professions' as a container for the expanding use of functions in the clinical and therapeutic domains.

The psychoanalytic professions were also expanding during the late nineteenth and early twentieth centuries, with a focus on case review as a form of "therapy for the therapist" (Carroll, 2007, p. 39). Freud (1910) has been credited with the development and expansion of psychoanalysis; however, others, such as Baldwin (1890), helped shape the new psychoanalytic theory and Josef Breuer, Freud's mentor, is credited with the development of the "talking or cathartic cure" (Breger, 2010, p. 6). Freud's focus on psychodynamic psychotherapy explored the underlying subconscious drives and motivations of the human personality. In his view, psychotherapists should themselves undergo regular psychotherapy to help them deal with the issues and challenges their clients bring to the therapy sessions. Freud's "Wednesday Society" (Munson, 2002a, p. 56), held at Freud's home, provided an early form of group supervision to discuss cases, treatment options and undertake "therapy for the therapist" (Carroll, 2007, p. 39).

With an increasing interaction between social work and therapy (Tsui, 2008), it is not surprising that the notion of functions also made its way into the therapeutic literature. Despite the analogous development in these fields, the literature related to supervision functions varies in both context and how the functions are applied. Proctor (2000) uses the term functions of supervision in terms of benefit to the supervisee, differentiating from Kadushin (1976), who described functions in terms of the role of the supervisor and in the context of the smooth running of the agency. Others, such as Bernard and Goodyear (2014), focus on the purpose of supervision, including the development and support for the supervisee, ideas which align with Proctor (2000). 
Ten distinct elements or foci of supervision are outlined in Table 1, excerpted from Hawkins and Shohet (1989, p. 43), with each aligned to the main categories of supervision identified by Kadushin (1976). Each element contributes to "developing an integrated style of supervision in relation to the educative, supportive and managerial roles" (Hawkins \& Shohet, 1989, p. 49), while the relational nature of supervision suggests an overlap between each of the categories.

\begin{tabular}{|l|l|}
\hline Key elements & Main categories of focus \\
\hline $\begin{array}{l}\text { To provide a regular space for the supervisees to reflect upon } \\
\text { content and process of their work }\end{array}$ & Developmental \\
\hline $\begin{array}{l}\text { To develop understanding and skills within the work } \\
\text { To receive information and another perspective concerning } \\
\text { one's work }\end{array}$ & Developmental \\
\hline $\begin{array}{l}\text { To receive both content and process feedback } \\
\text { To be validated and supported both as a person and as a } \\
\text { worker }\end{array}$ & Developmental/resourcing \\
\hline $\begin{array}{l}\text { To ensure that as a person and as a worker one is not left to } \\
\text { carry unnecessarily, difficulties, problems and projections } \\
\text { alone }\end{array}$ & Resourcing \\
\hline $\begin{array}{l}\text { To have space to explore and express personal distress, } \\
\text { restimulation, transference or countertransference that may } \\
\text { be brought up by the work }\end{array}$ & Qualitative/resourcing \\
\hline $\begin{array}{l}\text { To plan and utilize their personal and professional resources } \\
\text { better }\end{array}$ & Qualitative/resourcing \\
\hline To be proactive rather than reactive & Qualitative/resourcing \\
\hline To ensure quality of work & Qualitative \\
\hline
\end{tabular}

Table 1: Key functions of supervision (Hawkins \& Shohet, 1989, p. 43)

By contrast, Proctor (2000) reimagined the process of supervision being for the benefit of the supervisee, describing the functions as "formative, normative and restorative, or a framework of tasks between supervisor and supervisee within the working alliance model" (Proctor, 2000, p. 12). The working alliance model was first articulated by Bordin (1979) to describe the collaboration and mutual agreement between client and therapist or practitioner and supervisor, and is considered relevant in the context of coaching supervision.

The rapid expansion of both social work and psychoanalysis through the early decades of the twentieth century led to a number of shifts in the development of supervision. In the 1920s, supervision was based on the specific orientation of the therapist and needs of the individual, while in social work supervision was based on the needs of the agency to ensure the effective 
and efficient delivery of services to those in need. Along with this expansion there was a shift in focus relating to the functions of supervision. Supervision was not simply a process that took place in a collegial setting, but also "in the training context" (Proctor, 1994, p. 310). Increasing attention was also being paid to the developmental stages of trainees (Stoltenberg \& Delworth, 1987) and the role of the supervisor in ensuring the "confidence, competence and creativity" (Proctor, 1994, p. 309) of the individual practitioner.

There is little discussion in the literature on the functions of supervision in the context of coaching apart from the initial conceptualization by Hawkins and Shohet (1989). More recently Lucas and Larcombe (2016) comment on supervision supporting the business development function for independent coaches using the formative, normative and restorative classifications of Proctor (2000). In a similar vein, Clutterbuck et al. (2016a) make the point that the commercial reality of coaching may add to our understanding of the relevance or otherwise of supervision functions in providing development, support and quality assurance for coaching practitioners in a business context where there may be less focus on psychodynamic factors than in therapeutic settings.

\section{Extension: Functions in coaching supervision}

Over the past twenty years coaching has created an identity and rationale that is distinct from other domains. There are many definitions of coaching; however, for the purposes of this article, coaching will be defined as "partnering with clients in a thought-provoking and creative process that inspires them to maximize their personal and professional potential" (International Coaching Federation (ICF), 2018). Arguably, "coaching is different from other helping professions in that it is voluntary, works with healthy adults and is often focused in an organizational context" (Clutterbuck et al., 2016a, pp. 9-10), suggesting a need to expand the theoretical framework to include fields such as adult learning, organisational development, strategy, business development and systems thinking which are highly relevant in the complex business and executive coaching environment (Grant, 2005).

Little is known about the translation and adoption of supervision functions in relation to coaching apart from the initial descriptions of "developmental, resourcing and qualitative" (Hawkins \& Smith, 2006, p. 151). With an estimated fifty-three thousand coaching practitioners world-wide, an increase of 10\% since 2012 (International Coaching Federation (ICF), 2016, p. 8 ), a key argument of this paper is the need to build on what we already know 
about coaching supervision functions from the social work and therapeutic domains while focusing on the distinct nature and purpose of coaching to build individual and organisational capability. To date there are only two known papers (Clutterbuck, Whitaker, \& Lucas, 2016b; Lucas \& Larcombe, 2016) that have explored the notion of functions and their application in coaching supervision.

Noting that "in the evolution of coaching supervision literature, it is striking how much influence the therapeutic world has had" (Lucas \& Larcombe, 2016, p. 13), the challenges facing independent coaching practitioners led to a reconceptualization of the three core functions proposed by Proctor (2000). While maintaining the focus on professional development needs, Lucas and Larcombe (2016) highlighted the commercial challenges of independent coaches. The "formative would focus on articulating a coaching niche, the normative on how much a coach should charge and the restorative on having enough clients including the underlying question of is the individual a good enough coach" (Lucas \& Larcombe, 2016, p. 6).

In their discussion on functions in coaching supervision Clutterbuck et al. (2016a) consider the practical application of the various functions providing examples of how each could be used in the supervision process in areas such as "maintaining professional standards, increasing self-confidence, challenging blind spots and offering new perspectives" (Clutterbuck et al., 2016a, p. 9). Despite some similarities between each description of supervision functions, a number of differences are noted in relation to coaching, such as the "voluntary nature of supervision, robustness of coaching clients, multiple stakeholders and commercial context of coaching (Clutterbuck et al., 2016a, pp. 9-10). It is these differences that provide both the challenge and opportunity for further research and development related to coaching supervision.

Coaching and, by corollary, coaching supervision, operates within a particular context, and starts from an aligned and yet slightly different premise to other helping professions. While there are many shared theoretical underpinnings from psychology, adult learning, strategy, systems theory and others, as Brock (2012) points out coaching is yet to fully emerge from its philosophical roots, and develop models and theories which are specific to this field. Coaching is focused towards the future rather than the past, builds on strengths rather than dealing with problems, and is non-directive in its approach. This is a stance that is closely aligned with the developments in positive psychology (Csikszentmihalyi, 2009; Donaldson, Csikszentmihalyi, \& Nakamura, 2011; Seligman \& Csikszentmihalyi, 2000) which align to coaching 
with its focus on the future and on building individual and organisational capability. However, as Clutterbuck et al. (2016a) remind us, coaching has a number of distinctive characteristics in its independent nature and multiple stakeholders; factors which are also relevant in the context of commercial coaching supervision. Coaching supervision, at least in an organizational and executive coaching context, needs to help coaching practitioners manage the complexities of commercial and interpersonal environments.

\section{Towards an integrative view}

Writing in the context of residential social work, Hawkins (1982) argued that supervision has "three main focuses: management issues (including the carrying out of organizational and administrative tasks); work with the clients; and the work life of the individual being supervised" (Hawkins, 1982, p. 17). The "three circles model" (Hawkins, 1982, p. 19) offers one model of how functions integrate through the relationship between the supervisor and supervisee but does not explore this theme in any depth.

In their discussion on an integrative view of supervision, Carroll and Tholstrup (2001) present a kaleidoscope of supervision models from counseling and psychotherapy backgrounds, suggesting that an integrative view attempts to "connect the goals and purpose of supervision to the functions and tasks/roles of supervision" (Carroll \& Tholstrup, 2001, pp. 48-49). Supervision can be described as "a complex, technical, sensitive, and fairly new area of facilitating professional competence" (Hewson, 2001, p. 74), alluding to the need for a pluralistic view of supervision as both an art and a science. An integrated developmental approach to supervision reflects the earlier work of Stoltenberg (1997), and advocates an integration of functions where "the supervisor has to integrate the developmental role of educator with that of the provider of support to the worker and, in most cases, quality oversight of the supervisee's clients" (Hawkins \& Shohet, 2006, p. 4).

The table below provides a consolidated view of the functions of supervision from each domain of practice, the context in which they are used, and an alignment of terminology in each area, underscoring the continuing process of adaptation in each domain of practice. 


\begin{tabular}{ccccc}
\hline Author & $\begin{array}{c}\text { Kadushin } \\
(\mathbf{1 9 7 6 )}\end{array}$ & $\begin{array}{c}\text { Proctor } \\
\mathbf{( 2 0 0 0 , \mathbf { 2 0 0 8 } )}\end{array}$ & $\begin{array}{c}\text { Hawkins \& } \\
\text { Smith (2006) }\end{array}$ & $\begin{array}{c}\text { Newton } \\
\mathbf{( 2 0 1 2 )}\end{array}$ \\
\hline Domain & Social Work & Counseling & Coaching & $\begin{array}{c}\text { Transactional } \\
\text { Analysis }\end{array}$ \\
Context & $\begin{array}{c}\text { Role of } \\
\text { Supervisor }\end{array}$ & $\begin{array}{c}\text { Supervisee } \\
\text { benefit }\end{array}$ & Process & Transformation \\
& $\begin{array}{c}\text { Managerial } \\
\text { Supportive } \\
\text { Functions }\end{array}$ & $\begin{array}{c}\text { Formative } \\
\text { Restorative } \\
\text { Educational }\end{array}$ & $\begin{array}{c}\text { Qualitative } \\
\text { Resourcing } \\
\text { Developmental }\end{array}$ & $\begin{array}{c}\text { Accounting } \\
\text { Transformative }\end{array}$ \\
\hline
\end{tabular}

Table 2: Supervision Functions by domain and context - adapted from Newton (2012, p. 104)

In each of the domains and contexts, a number of common elements emerge. Mapping the three functions, as in the figure below, shows the number of connections between each function. Some license has been taken in associating key words, with 'quality' including managerial, qualitative, and accounting and 'development' offering a catch-all for education, development and transformation. Functions related to 'quality' are common between social work, coaching and transactional analysis, while the theme of 'development' is strongest between social work and coaching. This is not to suggest that 'quality' and 'development' functions are not important in counselling or transactional analysis or that 'supportive' and 'nurturative' functions are not useful in social work or coaching, rather this model shows where the greatest level of overlap occurs. Other connections may also be possible.

Arguably, each context is integral to the goal and purpose of supervision - to build the capability and confidence of the supervisee and support the best outcome for the client. The element that holds each of these in a more integrated frame is "a supervisory approach which is relationship based" (Hawkins \& Shohet, 1989, p. 5). In other words, there is joint accountability, with supervision being mutually supportive and beneficial to both supervisor and supervisee. 


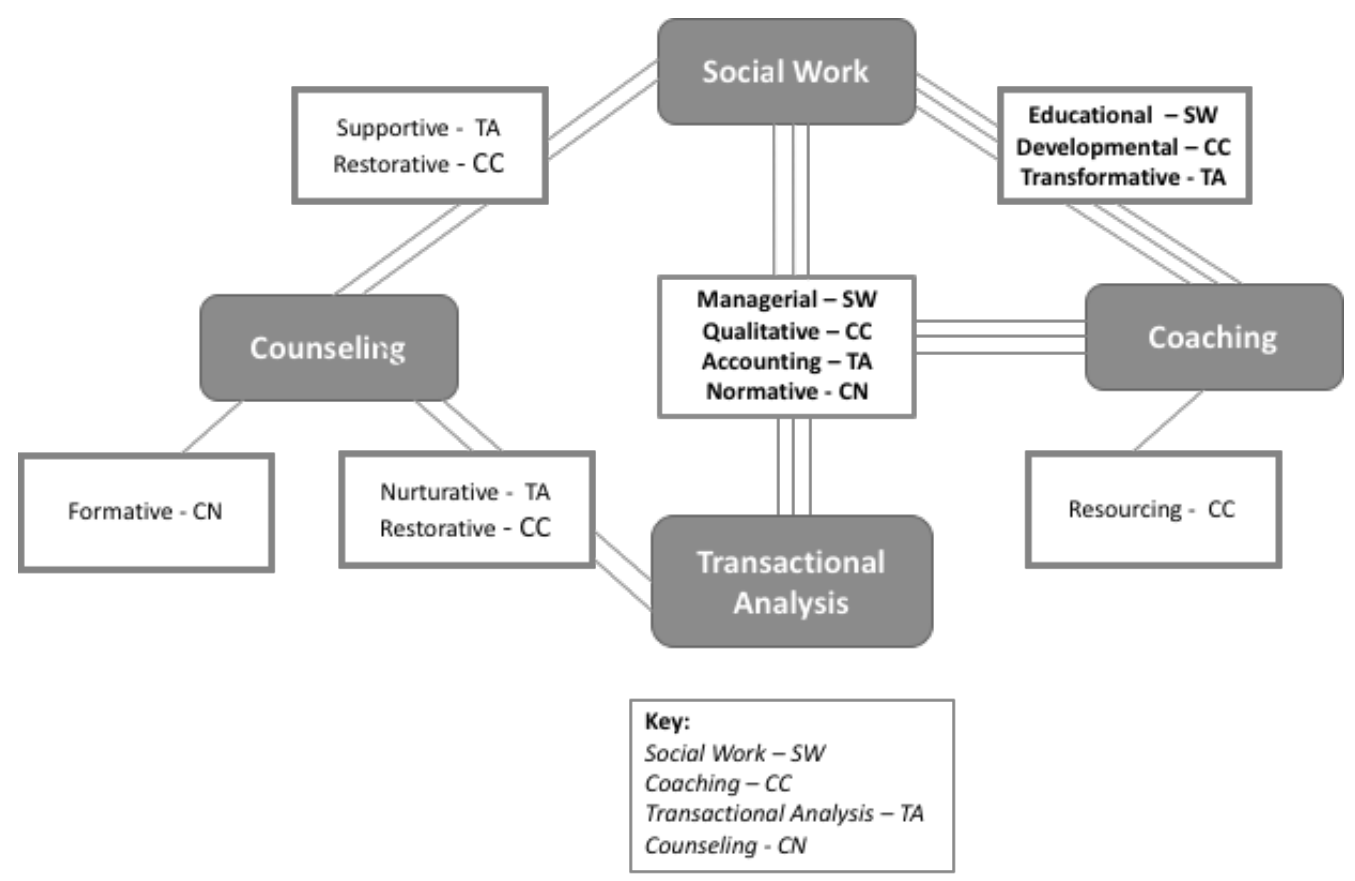

Figure 1: Map of connections between functions across each domain of supervision practice

In relation to coaching supervision, the key theme of the three functions is ensuring quality in meeting the needs of the client and developing the skills of the coaching practitioner (supervisee) which supports the process of building capability. For supervisors, this may mean incorporating a psychological approach to coaching supervision (Bluckert, 2005) and for Lucas and Larcombe (2016) this means understanding the commercial realities and organisational dynamics facing coaches.

Building on the earlier functions identified by Hawkins \& Shohet (2006), Kadushin (1976), and Proctor (2000), a paper from the field of transactional analysis suggests an integrative approach to the functions of supervision in terms of "three existential hungers for structure (accounting), recognition (nurturative) and stimulus (transformative)" (Newton, 2012, p. 104). The key suggestion is that ultimately supervision is as much a transformative experience as it is an administrative or supportive process.

While agreeing with Hawkins \& Shohet (1989) on the core functions of supervision for coaching, and that a holistic view of functions is important in the supervisory relationship, the challenge facing coaches, coaching supervisors 
and coaching organizations is that coaching covers many dimensions including life, career, business and executive, among others. Given that the core functions of supervision remain consistent, there is a need to define the tasks and roles of coaching supervisors and supervisees in many areas of coaching, including business and organisational environments where supervision may need to be more fast paced and pragmatic than in other fields.

Recent literature (Grant, 2017; Nelson-Jones, 2011) suggests that coaching and therapy are more closely aligned than they are different, and that the tasks and functions of supervision might be equally relevant no matter what the domain of practice. Others have raised the distinctive needs of coaching supervision, particularly for independent, commercially-oriented coaches (Clutterbuck et al., 2016b; Lucas \& Larcombe, 2016), suggesting the need to understand more about what is unique to the way that functions are described and applied in coaching supervision. As a 'helping profession' however, coaches and those who provide supervision services also need to be aware that issues of a personal and/or psychological nature may emerge in the context of coaching and that maintaining a psychological mindedness (Bluckert, 2005) is critical to ensure that boundaries of competence are maintained.

Coaching supervision, expressed as a need to provide on-going development, support and self-reflective practice for coaching practitioners, is still in its infancy. At a broader level, supervision is "an under-researched area of practice" (Beddoe \& Davys, 2016, p. 3) and "there are comparatively few empirically based studies of its content and practice, and the evidence for its effectiveness remains limited" (Carpenter, Web, Bostock, \& Coomber, 2012, p. 17). Irrespective of the specific domain of practice, it is worth reflecting on the overall purpose of supervision, which is "the professional development of the supervisee and the welfare of the client" (Carroll, 2001, p. 8). In coaching supervision, purpose is embodied through each of the three functions developmental, resourcing and qualitative - which provides supervisors and coaching practitioners with processes to improve the effectiveness of coaching.

This paper has provided an overview of supervision functions, tracing their emergence in social work, therapy and recent adaptation in the context of coaching supervision. There is an essential simplicity to the idea of three functions of supervision, no matter what the context. There is, however, a significant level of complexity in how each of supervision's 'three amigos' are described as tasks, roles, processes, benefits or purposes of supervision. Perhaps as Newton (2012) suggests, the real integration of functions is not about how to blend the words or integrate the functions, but takes place through 
the relationship or working alliance between the supervisor and the supervisee leading to a transformational experience for both and benefit to the client.

\section{References}

Baldwin, J. M. (1890). Handbook of psychology: Senses and intellect, 2nd ed., rev. NY, US: Henry Holt and Company.

Beddoe, L., \& Davys, A. (2016). Challenges in Professional Supervision. London: Jessica Kingsley Publshers.

Bernard, J. M., \& Goodyear, R. J. (2014). Fundamentals of Clinical Supervision (5th ed.). New Jersey: Pearson Education, Inc.

Bluckert, P. (2005). The foundations of a psychological approach to executive coaching. Industrial and Commercial Training, 37(4), 171-178.

Bordin, E. (1979). A Working Alliance Based Model of Supervision. The Counseling Psychologist, 11(1), 35-42.

Breger, L. (2010). Sigmund Freud A Discussion of my book: A Dream of Undying Fame: How Freud Betrayed His Mentor and Invented Psychoanalysis. Psychological Science. Retrieved from http://www.3quarksdaily.com/3quarksdaily/2010/05/psychologicalscience-sigmund-freud-a-dream-of-undying-fame.html

Brock, V. G. (2012). Sourcebook of Coaching History. North Charleston, SC: CreateSpace Independent Publishing Platform.

Carpenter, J., Web, C., Bostock, L., \& Coomber, C. (2012, October 2012). Effective supervision in social work and social care. Research Briefing 43. Retrieved from https://www.scie.org.uk/publications/briefings/files/briefing43.pdf

Carroll, M. (2001). Counselling Supervision. London, UK: SAGE Publications Ltd.

Carroll, M. (2007). One More Time: What is Supervision? Psychotherapy in Australia, 13(3), 34-40.

Carroll, M., \& Tholstrup, M. (Eds.). (2001). Integrative Approaches to Supervision. London: Jessica Kingsley Publishers.

Clutterbuck, D. A., Whitaker, C., \& Lucas, M. (2016a). Coaching Supervision: A practical guide for supervisees. London, UK: Routledge.

Clutterbuck, D. A., Whitaker, C., \& Lucas, M. (2016b). What is coaching supervision. In D. A. Clutterbuck, C. Whitaker, \& M. Lucas (Eds.), Coaching Supervision: A practical guide for supervisees (pp. 5-21). London, UK: Taylor \& Francis.

Csikszentmihalyi, M. (2009). The Promise of Positive Psychology. Psihologijske teme / Psychological Topics, 18(2), 203-211. 
Dan, V. (2017). An Exhaustive View on Supervision in Social Work: History, Evolution, Current Trends. Social Work Review / Revista de Asistenta Sociala (2), 147-159.

Dawson, J. B. (1926). The Case Supervisor in a Family Agency. Family (Social Casework), 6, 293-295.

Donaldson, S. I., Csikszentmihalyi, M., \& Nakamura, J. (Eds.). (2011). Applied Positive Psychology: Improving Everyday Life, Health, Schools, Work, and Society. New York, NY: Routledge.

Freud, S. (1910). The origins and development of psychoanalysis. The American Journal of Psychology, 21(2), 181-218. doi:10.2307/1413001

Grant, A. M. (2005). What is Evidence-Based Executive, Workplace and Life Coaching. In M. Cavanagh, A. M. Grant, \& T. Kemp (Eds.), EvidenceBased Coaching: Theory, research and practice from the behavioural sciences (pp. 1-12). Bowen Hills, QLD: Australian Academic Press.

Grant, A. M. (2017). Coaching as Evidece-Based practice: The View Through a Multiple Perspectives Model of Coaching. In T. Bachkirova, D. B. Drake, \& G. B. Spence (Eds.), The Sage Handbook of Coaching (pp. 62-84). London, UK: Sage Publications Ltd.

Hawkins, P. (1982). Mapping It out. Community Care, 22 (July 1982), 17-19.

Hawkins, P., \& Shohet, R. (1989). Supervision in the Helping Professions: An Individual. Group, and Organizational Approach. Birmingham: Open University Press.

Hawkins, P., \& Shohet, R. (2006). Supervision in the Helping Professions (3rd ed.). Berkshire. UK: Open University Press.

Hawkins, P., \& Smith, N. (2006). Coaching, mentoring and organizational consultancy: supervision and development. Maidenhead, UK: Open University Press.

Hewson, J. (2001). Integrative Supervision Art and Science. In M. Carroll \& M. Tholstrup (Eds.), Integrative Approaches to Supervision (pp. 65-76). London: Jessica Kingsley Publishers.

International Coaching Federation (ICF). (2016). 2016 ICF Global Coaching Study: Executive Summary. Retrieved from https://coachfederation.org/app/uploads/2017/12/2016ICFGlobalCoachi ngStudy_ExecutiveSummary-2.pdf

International Coaching Federation (ICF). (2018). Definition of Coaching. Retrieved from https:/coachfederation.org/about

Kadushin, A. (1976). Supervision in social work. New York, NY: Columbia University Press. 
Kadushin, A. (1991a). History, Definition and Significance. In Supervision in Social Work (4th ed., pp. 1-44). New York, NY: Columbia University Press.

Kadushin, A. (1991b). Supervision in Social Work. New York, NY: Columbia University Press.

Lucas, M., \& Larcombe, A. (2016). Helping independent coaches develop their coaching business: - a holistic approach to supervision or an opportunity for supervisors to exploit their position? International Journal of Mentoring and Coaching, IX(3), 1-16.

Munson, C. (2002a). Handbook of Clinical Social Work Supervision (3rd ed.). New York, NY: Haworth Press, Inc.

Munson, C. (2002b). History of Supervision. In Handbook of Clinical Social Work Supervision (3rd ed., pp. 49-94). New York, NY: Haworth Press, Inc.

Nelson-Jones, R. (2011). Theory and Practice of Counselling and Therapy (5th ed.). London, UK: SAGE Publications Ltd.

Newton, T. N. (2012). The Supervision Triangle: An Integrating Model. Transactional Analysis Journal, 42(2), 103-109.

Perlman, H. H. (1969). Helping: Charlotte Towle on Social Work and Social Casework. Chicago: University of Chicago Press.

Proctor, B. (1994). Supervision - competence, confidence, accountability. British Journal of Guidance \& Counselling, 22(3).

Proctor, B. (2000). Group Supervision: A Guide to Creative Practice. London, UK: SAGE Publications, Inc

Seligman, M. E. P., \& Csikszentmihalyi, M. (2000). Positive Psychology: An Introduction. American Psychologist, 55(1), 5-14.

Stoltenberg, C. D. (1997). The Integrated Developmental Model of Supervision: Supervision Across Levels. Psychotherapy in Private Practice, 16(2), 59-69. doi:10.1300/J294v16n02_07

Stoltenberg, C. D., \& Delworth, U. (1987). Supervising counsellors and therapists-A developmental approach. San Francisco, CA: JosseyBass.

Tsui, M. S. (2008). The Roots of Social Work Supervision: An Historical Review. The Clinical Supervisor, 15(2), 191-198. doi:10.1300/J001v15n02_14

\section{Acknowledgements}

The author gratefully acknowledges the assistance provided by Professor Daniel Harkness, PhD LCSW, School of Social Work, College of Health 
Sciences, Boise State University in locating an original copy of the article by John B. Dawson referred to in this paper.

The author would also like to acknowledge with appreciation the continuing support and guidance of his $\mathrm{PhD}$ supervisors - A/PR Grace McCarthy (UOW) and PR Julia Milner (EDHEC) and the positive feedback provided in the external review of this article. This research is supported by an Australian Government Research Training Program (RTP) Scholarship.

\section{Author Contact}

Mike Armour is a PhD candidate at the University of Wollongong. He can be contacted via email at mra612@uowmail.edu.au. 


\title{
Developing Leaders at Business Schools with Coaching Skills Aligned with the Goals of Responsible Management Education
}

\author{
Dorrian Elizabeth Aiken \\ Cape Town, South Africa
}

\author{
Salome Van Coller-Peter \\ Cape Town, South Africa
}

\begin{abstract}
The invitation for higher education institutions to transform curricula in line with the Principles for Responsible Management Education (PRME) and its 17 Sustainable Development Goals (SDG) sets the background for this paper. In this paper the authors reflect on the viability of providing experiential leadership development in business schools that delivers on the goals of sustainable development, drawing on integral theory and adult development theory. It suggests coaching competencies in particular as an experiential learning approach in the development of leadership ability, with specific focus on self-awareness and ethical relationship management in delivering on SDG.
\end{abstract}

Keywords: experiential learning, leadership development, responsible management education, sustainable development, business schools

\section{Introduction}

In September 2015, the United Nations adopted an agenda that set out a fifteen-year plan "to end extreme poverty, fight inequality and injustice, and protect our planet” (Principles for Responsible Management Education, 2016). The plan includes seventeen Sustainable Development Goals (SDGs) aimed at alleviating the most pressing challenges across the globe, with poverty alleviation, management of resources, economic reform, environmental and ecological sustainability, and ethical leadership being major concerns.

Responsible Management Education (RME) and the Sustainable Development Goals have clearly been linked to the role business schools can play in the development of potential leaders: while a focus on ethical leadership and sustainability has increased in corporations, a recent McKinsey interview reports that the speed and scale of what CEOs need to do is not sufficient (HBR, 2018). In light of RME recommendations, this paper focuses on the 
challenge in a business school context of developing future leaders and CEOs to meet some of the commitments set out in the SDGs.

Developing leadership competencies in those who need to lead in complex environments has been widely noted as challenging (Bennett, 2017; Berger, Hasegawa, Hammerman, and Kegan, 2007; Phillips, Hsieh, Ingene, and Golden, 2016). To be effective leaders in the 21 st century, according to several authors on this topic, business leaders require skills of technical excellence and experience and also the ability to understand and respond positively in relation to the complex range of human experience. They face a business world fast becoming unpredictable - often described as volatile, uncertain, complex and ambiguous. The speed at which change is taking place on several fronts threatens to outpace human capacity to keep up (Friedman, 2016; Kegan, 1994; Kegan and Lahey, 2014; Laloux, 2014; Brown, 2014; Bennet, 2017). In this article, we suggest an approach to developing resilient business leaders through the practical acquisition of coaching competencies. We argue that by the experiential development of practical coaching competencies in potential leaders, business schools can contribute to ethical, resilient leadership that can meet Sustainable Development Goals. This article also addresses the theoretical underpinnings that provide the rationale for skills viewed as critical to such leadership competencies.

\section{Setting the Leadership Development Context}

A case study, an international retail organisation with an enviable reputation for quality and service to its customers, illustrates our theme of developing relational leadership competencies to serve the RME agenda. In 2012, senior executives, who were aware that the organisation in South Africa was not retaining staff, decided upon remedial action: leadership development workshops. Staff members were to give frank feedback to their leaders on their conduct annually. Each year since 2012, in spite of costly leadership development training, staff members' opinions of leadership have become increasingly critical and distrustful, and the retention of good staff continues to be poor. Each year since 2012, leaders have sat down with their teams after the 360-degree feedback to have "an honest conversation" about what needs to change to improve connection between teams and their leaders. Staff members' dissatisfaction with their leaders came to a crisis point towards the end of 2016.

There is no doubt that the organisation's investment in leadership training was genuine and well-intentioned. The problem is that the training happens in a specially created hiatus, suspended outside the daily demands of the normal 
working week. However, after the training, nothing changed. Leaders returned to their teams, under pressure to catch up after their days of off-site training, and their default management and leadership behaviours kicked in. And so the disillusionment, distrust and disengagement of team members eventually increased to a flash point.

The experience described above is not unique in organisations. Petrie (2014) says in this regard:
smart, ambitious managers ... go to leadership development programs. The managers gather in a room, and a trainer teaches those new tools, techniques, and models for how to become a more effective leader. At the end of the program, everyone commits to making big changes back at work. The managers then return to the job and fall into the same old habits they had before the program. What's going on?

It seems, then, that leadership development workshops do not always succeed in achieving effective behavioural change on the job. Business schools are ideally placed to prepare future leaders; however, the question arises in the literature whether business schools are providing the kind of sustainable leadership and management skills that translate into positive impact on employees, let alone whether they achieve the global Sustainable Development Goals. Business schools have been criticised by some, especially since the financial crisis of 2008, for their dedication to business management theory where students are encouraged to adopt an attitude of self-interest and material enrichment (Giacalone \& Thompson, 2006, p. 267). Canals (2009) expresses the opinion that management models lack any sense of human presence. In her study of business schools in South Africa, the UK and the USA, Saunders (2011) comments that while there has been an increasing focus over the last decade on leadership and team-building skills within organisations, business schools have lagged behind in introducing team-building and leadership skills as theory or practice into the curriculum.

Is it fair to say that business schools neglect the human element? We find this critique somewhat harsh and certainly not entirely true of the content we facilitate at our own business school. MBA students are increasingly incorporating leadership theory into their programmes. However, the problem word here is theory. Wonderful tomes on leadership give insight into the importance of establishing positive relationships and ethical values-based interactions (Veldsman \& Johnson, 2016). Students engage individually or in cohorts to research and discuss their findings on leadership for the preparation of assignments and presentations. The issue is that, in the main and with few 
exceptions, the learning remains fragmented and at a cognitive level. Neuroscience research has found that acquiring sustainable new behaviours, such as would support values-based innovative leadership, is primarily a limbic brain function. As such it requires learning stimulated by experiential insight into self and continuous practice with others (see for example Sapolsky, 2017; Doidge, 2007, 2012; Lipton, 2008; Merzenic, 2014; Barrett, 2017). Although intended to be both challenging and supportive, even engagement in small groups is likely an exchange of views and information at the cognitive level. The degree of experiential and self-reflective learning, and the regular practising that is required by leaders to master sustained and skilful leadership behaviours, seems to be notably absent from mainstream MBA studies. As Muff (2013) maintains, textbook learning cannot serve as a substitute for ongoing practical experience.

The achievement of these leadership competencies depends upon an ongoing process of self-development, a life-style practice - not likely the outcome, as our case example at the start of this section illustrates, of a threeday or even ten-day leadership development programme. As Petrie (2014) has commented, leadership development should be an ongoing process, "not an event." Thus, in increasingly volatile and unpredictable environments, we argue that leadership is a basket of skills that would benefit from the inclusion of coaching competencies, requiring daily practice on the job - a practice that should (and in some places, already does) begin at business school. To return to the above-mentioned case study, leaders in the troubled organisation cognitively understood the connection between the quality and consistency of positive engagement with their teams and their performance. However, the translation of this cognitive knowledge into daily practice of behaviours on the job with their teams has not yet become a non-negotiable requirement. In support of the RME agenda, business schools have the opportunity to integrate coaching practices as a non-negotiable part of leadership behaviours along with technical business skills in order to meet volatile, unpredictable relationship challenges.

\section{A Coaching Approach For Leadership Development}

In University of Stellenbosch Business School's MPhil in Management Coaching programme we aim to develop leaders and managers who are competent coaches, in the belief that the requisite skills of a good coach grow more awareness of complexity and ambiguity and consequently build more resilience in leaders. A core focus of the programme is how the students discover subjectivity, or the ways in which their views of reality have been constructed - what they have chosen to believe and the lenses through which 
they have interpreted and engaged with the world. Construct development theorists like Robert Kegan (2016), Susan Cook Greuter (2005), Bill Torbert (2004) and Barrett Brown (2012) have provided frameworks that illustrate constructs at the different stages of adult development, from limited complexity and perspective-taking to multiple ways of seeing and engaging with the world.

\section{Vertical Learning}

We conjecture, based on evidence issuing from the work of Susanne Cook Greuter (2005) and her Leadership Maturity Framework, as well as the MetaIntegral Institute, to name just two examples, that business schools can create environments that are conducive to growing awareness in potential business leaders of more complexity and perspective-taking than they may currently be aware of, particularly at an emotional and interpersonal level. Such increased conscious awareness, the process of vertical learning, may enable leaders to inspire teams and find solutions to some of the world's most pressing challenges as set out in the Principles of Responsible Management Engagement.

Both horizontal (translational) learning and vertical (transformational) learning are important in leadership development (Petrie, 2014). In this context, horizontal learning refers to the process of increasing knowledge and competencies - what leaders should know and do. It is primarily a function of cognitive (neocortical brain) intelligence. Vertical growth refers to an increase in a person's ability to think in increasingly complex ways, to be comfortable with multiple perspectives and to connect meaningfully across differences. Holding such complexity with ease is a function of emotional and interpersonal intelligence, more likely part of coaching training than conventional leadership development with its emphasis on developing cognitive intelligence. In a white paper entitled The Future of Leadership for Conscious Capitalism (MetaIntegral Associates, 2014), Barrett Brown claims that vertical learning is a natural stage-development process, but that it can be accelerated significantly under the right conditions. He notes that, by and large, leadership development is a horizontal learning process in conventional, tradition-based programmes, yet leading centres at Harvard, Stanford and Cambridge place vertical learning at the core of their prestigious leadership development programmes.

Furthermore, he cites the Centre for Creative Leadership as naming vertical learning the number one future trend in leadership development.

As Laloux (2014) demonstrates in his research on organisations, when individuals are surrounded by colleagues who hold more complex views of the 
world, and they feel safe enough to reflect on conflicting points of view, there is a strong likelihood of a shift to embracing multiple perspectives. These capabilities suggest themselves as appropriate to meet the challenges of the SDGs. Laloux also shows that when employees are managed by leaders who see and engage with them in more complex ways, and whose behaviours are respectful and inclusive of all levels of staff, overall performance improves. However, leaders in these organisations first need to know how to include and elevate others to the required level of thinking and operating. Indeed, the model or framework suggested for the focus and implementation of SDGs emphasises, among six other imperatives, top-down commitment from leadership and bottom-up commitment from faculty and staff. We conjecture that leaders with a skilful coaching style stand a greater chance of success in engaging positive commitment from employees because of the fundamental principles of coaching: listening attentively, building trust, encouraging potential, and ensuring accountability.

\section{The process of developing leaders with a coaching style}

A long part of the journey to becoming a coach is to be comfortable with accepting who we are, what we think and how we behave. Undoubtedly, the skill that facilitates the most transformation during the process of becoming a coach is that of reflective practice. As part of the MPhil in Management Coaching, students' reflective practices are built up from a simple model like Borton's (1970) to the more intricate model of Kimber (2003). Borton's model asks three simple questions: What came up for you during a learning activity that caused an 'aha' moment? The next questions ask: So what? How is it significant for you? What did it trigger within you that is worth exploring on your learning journey? The third questions ask: Now what? How can you capitalise on the new insight to further your thinking and practice so as to enhance your competence in providing a richer coaching experience for both your client and yourself?

A step-up in complexity from Borton's model, Kimber's model encourages reflection on three different levels, leading from surface evidential data or Level 1 content to Level 2 (what process is used to unpack the content) and Level 3 (what premise underpins and informs the content and process). Thus, insight is deepened by developing awareness of our own processes of learning and thinking, as well as becoming intrigued by the sense-making of others. Becoming aware of constructs and meaning-making is significant for coach training if leaders are to help others recognise not only their own constructs, but also the possibility for multiple ways of making meaning. 


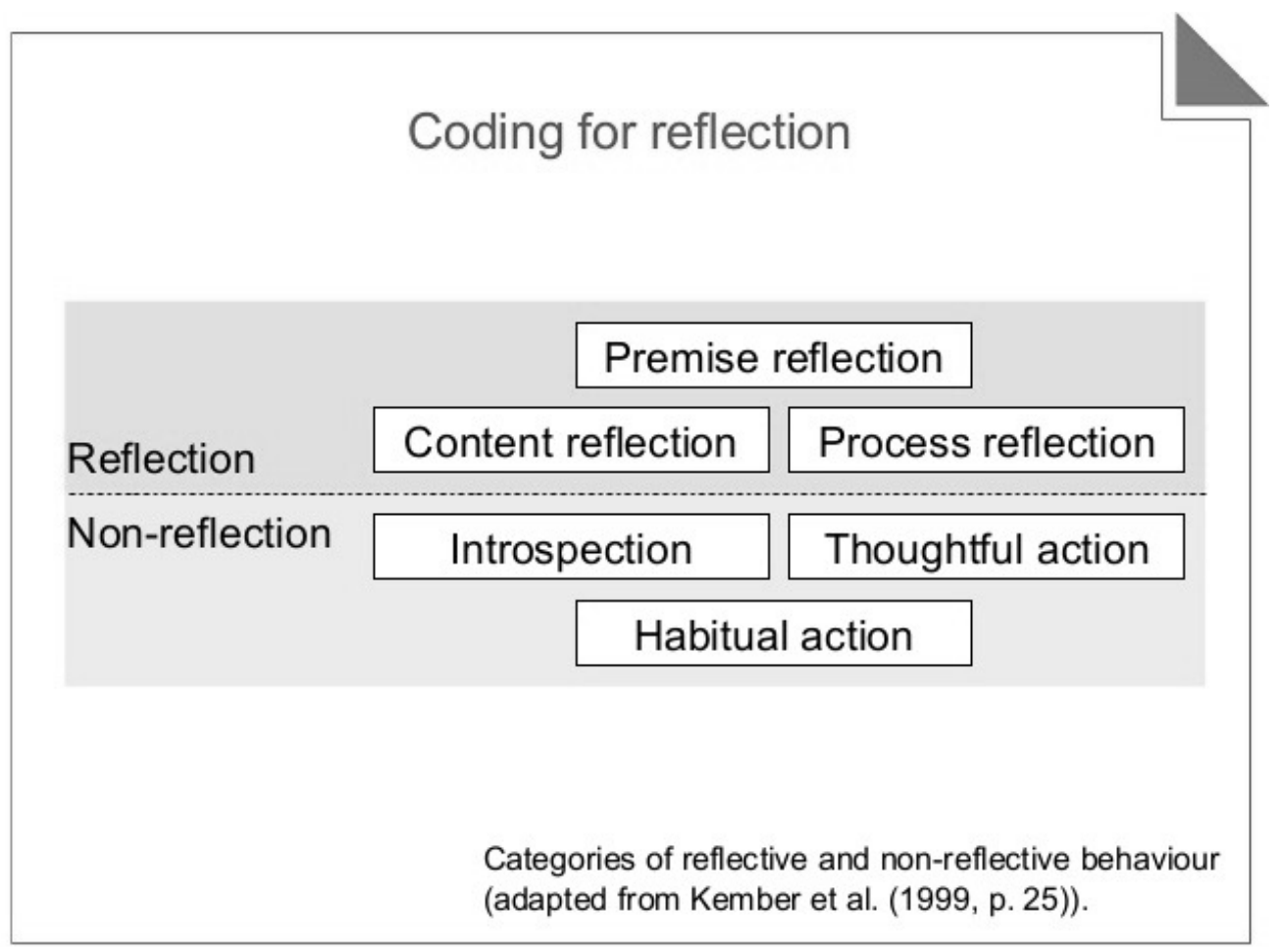

Figure 1: Analysing reflections

Good coaching skills focus on how leaders consistently engage with stakeholders, colleagues and staff, along with the technical competencies of what they are expected to achieve. Good coach training translates leadership development theory into positive engagement. We have already described the practice of self-reflection. Neuroscience emphatically confirms that sustained behaviour change takes place only with iterations of practice, with practical experiences that challenge beliefs, values, emotions and habits (Doidge, 2007; Lipton, 2008; Merzenich, 2013; Lewis, Amini, and Lannon, 2001). As stated earlier in this article, reading a book, no matter how brilliant, is unlikely to bring about sustained behaviour change. The many leadership and self-help books that abound are testimony to the impotence of cognitive intelligence (a neo-cortical brain function) to influence emotional and interpersonal intelligence (a limbic brain function) in the absence of direct experience (Lewis et al, 2001, p. 118). Neuroplasticity, the ability for new neural pathways to develop in the brain in response to sustainable new learning, is possible for everyone - the caveat is that it requires practice. What follows are some of the other critical skills for developing leaders with a coaching style. 


\section{Critical skills for ethical leadership with a coaching style}

Leaders require particular skills to function optimally in a volatile, fastchanging world. Here we focus on the art of listening, building trust, and engaging the power of the limbic brain.

\section{The art of listening}

Kevin Sharer (2012), the CEO of Amgen, says of the art of listening:

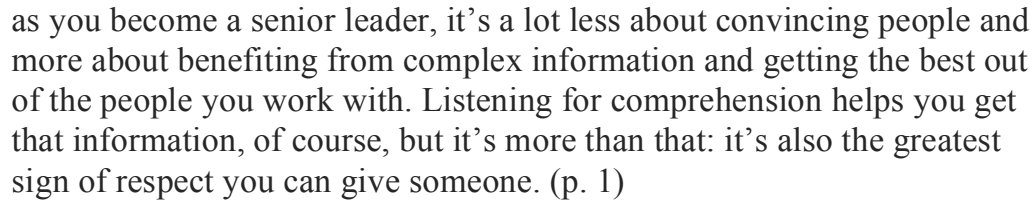

The practice of truly listening without allowing the intrusion of one's own thoughts and without interruption or asking leading questions is a powerful discipline in developing vertical altitude. It requires more mature egos: such leaders are less prone to knee-jerk reactions or acting on split-second judgements, and more capable of impulse control (Charan, 2012). Apart from the benefits for the listener in maturing leadership ego, the benefits for the thinker are numerous: the positive impact of being heard, of having uninterrupted time to think and, as a consequence, feeling valued as an employee, team member or colleague (Zak, 2017). Google's two-year search for the ideal team conditions (Duhigg, 2016) led to the discovery that, quite simply, the building blocks were being heard, feeling valued and thereby creating trust. However, it is a journey from discovering the right leadership ingredients to the leader being able to bake the perfect team cake.

Our students in the MPhil in Management Coaching programme begin with three-minute practice sessions, in pairs, giving perfect attention to a fellow student. At the first few attempts of simply allowing someone to do his or her own free thinking for just three minutes, without interruption or asking questions generated by their own curiosity, the listeners were asked how difficult it was to give this kind of attention unconditionally. With ongoing practice during the course of the year, the emotional and interpersonal maturity of the listeners increased significantly. This advance in their development became visible in the quality of their attention to the thinker, and in being able to hold silence and create the conditions to keep the thinker deeply engaged with the topic. The impact on the thinker, when the listening is this good, is 
unfailing appreciation for the depth and richness of the experience (Kline, 1999) .

Trust and the power of the limbic brain

Zak (2017) says the following about trust:

Leaders understand the stakes - at least in principle. In its 2016 global CEO survey, $\mathrm{PwC}$ reported that $55 \%$ of CEOs think that a lack of trust is a threat to their organization's growth. But most have done little to increase trust, mainly because they aren't sure where to start.

Students in our Masters in Management Coaching programme are introduced to David Rock's SCARF (Rock 2008), an effective, accessible model which describes five key triggers to the limbic brain. The students are able to engage emotionally with the positive and negative impact of these five triggers - status, certainty, autonomy, relatedness and fairness - drawing on their own experiences. Research provides the evidence that emotionally intelligent leaders build trust, engender loyalty, and enhance motivation when they consciously affirm status, give certainty and autonomy and assure fairness (Ringleb, Rock \& Ancona 2012). The ability to build positive relationships with SCARF in mind is an important component of learning to lead effectively by making use of coaching competencies (Rock, 2006).

\section{Conclusion And Recommendations}

This article focused on developing coaching skills that emphasise reflective awareness in current and future leaders studying at business schools. Our belief, based on our own experience at University of Stellenbosch Business School, is that business schools can play a powerful role in accelerating vertical learning by training potential business leaders to use coaching skills to create more resilient business environments. We conclude this opinion piece with these questions for business schools (developed by Saunders (2011), drawing on the unpublished dissertation of Coetzee (2009)):

- What future does humankind want?

- What kind of society will create this future?

- What kind of business does this type of society require?

- What kind of leader does this kind of business need?

- What kind of MBA does this kind of business leader need? 
Based on this set of questions and the discussion in this article, we draw the following conclusions about the mindsets that professional ethical leaders need, and the experiential practices that business schools need to instil in order to fulfil the RME agenda by 2030. In considering the theory and practices and in particular the concept of vertical learning, we suggest that leadership ability to implement the RME goals in the next ten to fifteen years be facilitated by the inclusion of coaching skills at business schools that aim to increase developmental consciousness and complexity in future leaders by experiential learning. Such leaders in the workplace would then continue to raise the standard of trustworthy, innovative and resilient leadership in the pursuit of achieving the Sustainable Development Goals so critical to the improved wellbeing of all.

\section{References}

Barrett, Lisa Feldman. (2017). How emotions are made: The secret life of the brain. UK: Macmillan

Bennett, K. (2017). Living and Leading Through Uncertainty: Developing leaders' capability for uncertainty. Sandton: Knowledge Resources.

Berger, J.G., Hasegawa, B., Hammerman, J. and Kegan, R. (2007). How Consciousness Develops Adequate Complexity to Deal With a Complex World: The Subject-Object Theory of Robert Kegan. Available online: http://terrypatten.typepad.com/iran/files/keganenglish.pdf [Accessed: 17 January 2017].

Brown, B.C. (2014). The Future of Leadership for Conscious Capitalism. MetaIntegral Associates.

Brown, B.C. (2012). Conscious leadership for sustainability: How leaders with a late-stage action logic design and engage in sustainability initiatives. Doctoral dissertation. California: Fielding Graduate University.

Cacioppe, R. and Edwards, M. (2005). Seeking the Holy Grail of organisational development: A synthesis of integral theory, spiral dynamics, corporate transformation and action inquiry. Leadership \& Organization Development Journal, 26(2), 86-105. http://dx.doi.org/10.1108/01437730510582536.

Canals, J. (2009). Seeking a greater impact: New challenges for business schools. Retrieved from http://www.iese.edu/research/pdfs/DI-0838E.pdf

Charan, R. (2012, June). The Discipline of Listening. Harvard Business Review. Retrieved from https://hbr.org/2012/06/the-discipline-oflistening 
Cook-Greuter, S. (2005). Ego Development: Nine Levels of Increasing Embrace. Retrieved from: http://areas.fba.ul.pt/jpeneda/CookGreuter.pdf [Accessed: 27 January 2017].

Doidge, N. (2007). The Brain that Changes Itself. New York: Penguin. Doidge, N. (2015). The Brain's Way of Healing. New York: Viking.

Duhigg, C. (2016, Feb). What Google Learned from its Quest to Build a Perfect Team. New York Times Magazine. Retrieved from https://www.nytimes.com/2016/02/28/magazine/what-google-learnedfrom-its-quest-to-build-the-perfect-team.html

Friedman, T. (2016) Thank you for being late: An optimist's guide for thriving in an age of acceleration. New York: Farrar Straus and Giroux

Gentile, M. (2014). The Holy Grail: Educating for values-driven leadership across the curriculum and giving voice to values. EFMD Global Focus, $8(1)$.

Giacalone, R.A. and Thompson, K.R. (2006). Business ethics and social responsibility education: Shifting the worldview. Academy of Management Learning \& Education, 5(3), 266-277. Doi: 10.5465.AMLE.2006.22697016.

HBR, 2018. McKinsey's Head on Why Sustainability Efforts Are Falling Short. Harvard Business Review Ideacast. Retrieved from https://hbr.org/ideacast/2018/03/mckinseys-head-on-why-corporatesustainability-efforts-are-falling-short

Kegan, R. and Lahey, L. (2016). An Everyone Culture: Becoming a deliberately developmental organisation. Brighton, Massachusetts: Harvard Business Review Press.

Kegan, R. (1994). In Over Our Heads: The mental demands of modern life. Brighton, Massachusetts: Harvard Business Review Press.

Kegan, R. (1982). The evolving self: Problem and process in human development. Cambridge, MA: Harvard University Press.

Kline N. (1999). Time To Think: Listening to Ignite the Human Mind. UK: Wardlock

Koljatic, M. and Silva, M. (2015). Do Business Schools Influence Students' Awareness of Social Issues? Evidence from Two of Chile's Leading MBA Programs. Journal of Business Ethics, 131(3), 595-604. DOI 10.1007/s10551-014-2295-4.

Laloux, F. (2014). Reinventing Organizations: A guide to creating organizations inspired by the next stage of human consciousness. Millis, MA: Nelson Parker.

Lewis T, Amini F, Lannon R. (2001). A General Theory of Love. New York: Vintage 
Lipton, B. (2008). The Biology of Belief. Unleashing the Power of Consciousness, Matter \& Miracles. California: Hay House Inc.

Merzenich, M. (2013). Soft-wired: How the new science of brain plasticity can change your life. San Francisco, California: Parnassus Publishing.

Mitroff, I. (2004). An open letter to the deans and faculties of American business schools. Journal of Business Ethics, 54, 185-189.

Muff, K. (2013). Developing globally responsible leaders in business schools: A vision and transformational practice for the journey ahead. Journal of Management Development, 32(5), 487-507. Doi: $10.1108 / 02621711311328273$.

Petrie, N. (2014). Vertical Leadership Development - Part 1. Developing Leaders for a Complex World. Center for Creative Leadership. Retrieved from http://www.nicholaspetrie.com/vertical-leadershipdevelopment [Accessed: 17 January 2017].

Phillips, F., Hsieh, C.H., Ingene, C. and Golden, L. (2016). Business schools in Crisis. Journal of Open Innovation, 2(10). Doi:10.1186/s40852-0160037-9.

Ringleb, A. \& Rock, D. (2008). The emerging field of neuroleadership. NeuroLeadership Journal, (1), 3-19.

Ringleb, A., Rock, D., \& Ancona, C. (2012). Neuroleadership in 2011 \& 2012. NeuroLeadership Journal, (4), 1-34

Rock D. (2006). A Brain-based Approach to Coaching. International Journal of Coaching in Organisations, 4(2), 32-43.

Rock, D. (2008). SCARF: A brain-based model for collaborating with and influencing others. NeuroLeadership Journal, (1). Retrieved from https://www.epa.gov/sites/production/files/201509/documents/thurs_georgia_9_10_915_covello.pdf

Sapolosky, Robert. (2017). Behave: The biology of humans at our best and worst. UK: Bodley Head.

Scharmer, O. and Kaeufer, K. (2013). Leading from the Emerging Future. San Francisco, CA: Berrett-Koehler.

Sharer K. (2012, April). Why I'm a Listener. McKinsey Quarterly. Retrieved from https://www.mckinsey.com/featured-insights/leadership/why-im-alistener-amgen-ceo-kevin-sharer

Principles for Responsible Management Education: An Initiative by the United Nations Global Compact. (2016). Transformational Model for Prime Implementation. Retrieved from http://www.unprme.org/resourcedocs/PRMETransformationalWeb.pdf

Veldsman, T. H. and Johnson, A. J. (Eds). (2016). Leadership. Perspectives from the Front Line. Randburg: KR Publishing. 
Torbert, W. (2004). Action Inquiry: The secret of timely and transforming leadership. San Francisco, CA: Berrett-Koehler.

Whiting, J., Jones, E., Rock, D. and Bendit, X. (2013). Lead Change with Brain in Mind. NeuroLeadership Journal, (4). Retrieved from

http://implementconsultinggroup.com/media/2949/lead-change-withthe-brain-in-mind.pdf

Zak, P. (2017, Jan-Feb). The Neuroscience of Trust. Harvard Business Review. Retrieved from https://hbr.org/2017/01/the-neuroscience-of-trust 


\title{
Coaching To What End? The Development and Enactment of a Shared Critically Oriented Coaching Discourse
}

\author{
Laura M. Lang \\ Wisconsin, USA
}

\begin{abstract}
To what end do coaches carry out their work within schools? Literacy and instructional coaches are positioned as leaders within their schools and districts. In these leadership roles, the purposes and intended outcomes of coaching are often assumed. Using data collected during an 18-month qualitative study of four high school literacy coaches, along with critical theories of leadership and literacy, the author/participant researcher traces the development of the coaches' shared discourse and considers what could be possible if coaches considered themselves critically oriented leaders. Finally, a framework for critically oriented coaching is briefly introduced in the context of this data.
\end{abstract}

Keywords: instructional coaching, critical theory, instructional reform, coaching beliefs

As a current instructor within a university-based online coaching certificate program, I have the opportunity to interact with school-based coaches from all over the world. Coaches from Brazil, the United States, Colombia, and many other countries often reveal tensions between the instructional reforms they are asked to support and the work they believe should be prioritized. Instructional coaches are typically hired to improve student learning, either within a single school or in multiple schools. In these varied contexts, instructional reforms assume multiple forms, and they can be propelled by national or state policies, by school leadership, or by the teachers themselves. They can take the form of a prescriptive literacy or math curriculum, of mission-driven learning goals within a school, or of needs identified by individual teachers.

As each new cohort of instructional coaches advances through our certificate program, the following becomes more evident: the "why" of coaching, while it appears self-evident, is imbued with tacit beliefs about learning, teachers, students and school reform. Elliot, an instructional coach currently working in Colombia, was trained to support the implementation of a new literacy curriculum in his international school. Though he supports this curriculum, he struggles to reconcile a curriculum-focused model of coaching

This is an Open Access article distributed under the terms of the Creative Commons Attribution (CC BY) License which permits use, distribution and reproduction in any medium, provided the original work is properly cited. 
with his own preference for inquiry-based and student-centered models of coaching (e.g. Costa \& Garmston, 2002; Sweeney, 2011; Aguilar, 2013). He explained, "I can't sculpt this [teacher] into a mini-me of what I think teaching should look like." Like many coaches who encounter these tensions (Rogers, 2014), Elliot is grappling with a question that is fundamental to the coaching role: To what end am I coaching?

In my current role as a university-based educator, I encourage others to wrestle with this question through a combination of readings, discussion prompts and application activities. During the six years I spent working as a high school literacy coach, I wrestled with this question daily as I sought to reconcile my beliefs about equity-driven reform with the reforms I was asked to help teachers enact. This article presents data from an 18-month qualitative case study that I conducted with four high school literacy coaches in the Lake City School District. I was one of the four literacy coaches. At that time, my concurrent role as a doctoral student provided an opportunity for me to study our interactions and explore "To what end" we understood and enacted our coaching roles. This article traces the development of our shared discourse about instructional reform and literacy instruction, a discourse that reflected critical theories about leadership and literacy. Ultimately, a framework for critically oriented coaching is briefly introduced to catalogue how we enacted those beliefs in our coaching practice.

\section{Coaches as instructional leaders...to what end?}

Michael Apple $(2000,2018)$ reminds us that schools have historically been, and will continue to be, sites of struggle over fundamental democratic processes, what counts as knowledge and whose knowledge is privileged. Instructional reforms, though they differ in focus and scope, are manifestations of the struggle Apple describes, as they embody specific priorities about what kinds of learning should be privileged and where resources should be allocated. Embedded within these reforms are theoretical assumptions about the purpose of reform and about the purposes and intended outcomes of teaching and learning (Capper, 1998; Sirotnik \& Oakes, 1986; Apple, 2006).

As instructional leaders, literacy coaches are positioned at the center of this struggle, as they are charged with helping to improve literacy instruction within a school building. In this capacity, they are expected to support and promote instructional reform (Neufeld \& Roper, 2003; Sturtevant, 2003; IRA, 2006; Carnegie Council for the Advancement of Adolescent Literacy, 2010; Fullan, 2010). However, because their formal job descriptions are sometimes 
non-existent, insufficient or evolving, their roles can be undefined and/or ambiguous (Blamey, Meyer \& Walpole, 2008; Mraz, Algozzine \& Watson, 2008). Subsequently, they must often negotiate the "To what end?" of their work while interacting with teachers and administrators. Within schools struggling to meet the needs of a diverse student body, conversations about the intended outcome of coaches' efforts are even more crucial. Below, I share the context that allowed Lake City School District coaches to explore the "Why" and "To what end" of their work.

\section{The Coaching and Research Context}

The Lake City School District (LCSD) is a midsize urban district within the Midwestern United States. Lake City residents have access to a world-class university system, cutting-edge technology firms and multiple high-demand industry jobs. However, LCSD data also reveals stark and persistent academic achievement gaps defined by socioeconomic status and race.

At the time of this study, LCSD high schools served approximately 7,550 students in grades 9-12, and the student population reflected a diverse range of socioeconomic, ethnic, racial and religious backgrounds. Approximately 55\% of students identified as White, 23\% Black, 12\% Hispanic, 10\% Asian and 1\% American Indian. $42 \%$ of students enrolled in the district were identified as economically disadvantaged. During the same year, only $48 \%$ of students identified as economically disadvantaged scored proficient or advanced on the state's reading assessment. Similarly, while $89 \%$ of White $10^{\text {th }}$ graders scored either proficient or advanced, only $49 \%$ of Black students and $53 \%$ of Hispanic students scored proficient or higher.

The LCSD coaches were cognizant of these stark achievement gaps and understood that we had been hired to help teachers improve the literacy achievement of all students.

\section{The Participants}

Rachel, Sharon, Carol and I were all the first titled literacy coaches within the Lake City School District. When this study began, we had been working together for approximately one year. Our positions were funded through a federal grant designed to help LCSD address the academic inequities detailed above. We did not know each other prior to entering these positions, and we were each assigned to coach in one of LCSD's four comprehensive high schools. However, we soon entered a fledgling community of practice (Wenger 
et al., 2002) that would sustain, challenge and influence our work. This community of practice, the Literacy Coach Collaborative (LCC), will be described in more detail below.

All participants provided signed consent to participate in this study, including district staff members who attended some of our LCC meetings. Due to a recent shift in district priorities and role titles, Carol, Rachel and Sharon no longer work as titled literacy coaches; however, some are still employed in the district. Consequently, I have taken additional precautions to protect their identities. All names of places and participants except mine have been assigned pseudonyms. In addition, details about Carol, Sharon and Rachel are shared below in aggregate.

Prior to entering their high school coaching positions in the fall of 2008, my three colleagues had worked as a secondary English teacher, a middle school English as a Second Language teacher, and a Special Education teacher. Two of the three had Reading Specialist or Reading Teacher certifications; one did not. I entered the coaching role with ten years of experience teaching English Language Arts and reading in both urban and suburban high schools, and I was certified as a Reading Specialist. In addition, I was the only one who had formal literacy coaching experience prior to our work in LCSD. We all identify as white females; in different capacities, we had all worked to support students who had been marginalized within the school setting.

\section{Research Methods}

During the 18-month study, I interviewed each coach three times using a semi-structured protocol. In addition, Literacy Coach Collaborative meetings were audiotaped and transcribed. On two occasions, a district staff member asked me to pause the audio recorder when particularly sensitive information was being discussed. The resulting transcripts of these meetings, in addition to participant interview transcripts and retrospective field notes, were analyzed using both inductive and deductive coding methods (Saldaña, 2009). Also included in the data set were district-generated public documents related to instructional reforms discussed by the coaches.

\section{Researcher's Role}

As a participant researcher, I was acutely aware that "Neither the insider nor the outsider is gifted with immaculate perceptions" (Erickson, in CochranSmith \& Lytle, 1993, p. ix). In addition to maintaining detailed retrospective 
field notes, I also generated notes about my experiences as a participant researcher. I reflected on how I was representing others' experiences, paying particular attention, as Zeni recommends, to how each participant defined issues I assumed to be significant or problematic (2001, p. xvii). Finally, I conducted frequent member checks with my participants, giving them opportunities to confirm, clarify or question my findings.

\section{Cultivating a shared discourse}

\section{The Literacy Coach Collaborative}

While we worked in separate high school buildings, Rachel, Carol, Sharon and I met biweekly, either with district staff or by ourselves, to plan together, learn together and address specific challenges that we were each facing. The Literacy Coach Collaborative meetings took on various shapes and sizes as our work progressed and as our relationship with the LCSD districtlevel staff evolved. We met in each other's schools, the district administration building, or centrally located coffee shops. The focus of each meeting varied, depending on who was in attendance and what school or district-related initiative was prioritized at the time.

In addition to sharing insights and solving problems together, we developed tools - such as job descriptions and literacy guides - that required us to enter into negotiations around the language choices that would best reflect our beliefs. It is important to note that we were not always in agreement regarding precisely what reading and writing skills should be prioritized as we worked to design professional development opportunities within our own buildings. As mentioned previously, we entered into our coaching position with different professional experiences in education. However, the creation of shared coaching tools and resources gave us opportunities to develop and name those core beliefs about our work. Table 1 categorizes the kinds of work that we engaged in during these biweekly meetings. 


\begin{tabular}{|l|l|}
\hline $\begin{array}{l}\text { Technical } \\
\text { Work }\end{array}$ & $\begin{array}{l}\text { Share resources; Learn more about district initiatives and } \\
\text { resources; Generate ideas for solving coaching-related } \\
\text { challenges in our building; Design professional } \\
\text { development opportunities }\end{array}$ \\
\hline $\begin{array}{l}\text { Professional } \\
\text { Identity Work }\end{array}$ & $\begin{array}{l}\text { Define the coaching role; Craft common definitions of } \\
\text { terms (i.e. literacy); Define ideal relationship with our } \\
\text { administrators and district staff; Discuss and articulate our } \\
\text { role in relation to change }\end{array}$ \\
\hline $\begin{array}{l}\text { Instructional } \\
\text { Reform Work }\end{array}$ & $\begin{array}{l}\text { Articulate core beliefs about reform; Develop shared list of } \\
\text { best-practice literacy strategies; Strategize about enactment } \\
\text { and critique of instructional reform; Negotiate with district } \\
\text { staff }\end{array}$ \\
\hline
\end{tabular}

Table 1: Types of work carried out during Literacy Coach Collaborative meetings

During the LCC meetings, we engaged in sensemaking (Weick, 2001) around our coaching practice, our professional identities and our relationship to instructional reform. Rachel explained the role that the Literacy Coach Collaborative played for her.

\footnotetext{
I can't even begin to describe the sense of relief and community that the LCC has provided. I don't know if I'd still be in this position if I didn't have you guys to depend on. Being in the same boat and having your expertise and your support to rely on. And also an occasional pat on the back.
}

Because no formal coaching model was being utilized within the district at the time, the LCC meetings provided us with opportunities to discuss, compare and negotiate our beliefs with each other and with district-level staff who were present. The LCSD literacy coaches' community of practice, and the shared discourse (Bakhtin, 1984; Gee, 2011) that resulted, was constructed collaboratively by the four coaches as we engaged with the challenges we faced within our new roles and as we responded to various district requests and opportunities.

\section{Theories about language-in-use}

A focus on the coaches' shared discourse is predicated on the assumption that language is always political and that it has the power to both reify and transform existing hegemonic norms within an institution (Fairclough, 1989; Janks, 2010; Gee, 2011). Gee explains that "language simultaneously reflects contexts (what's out there in the world) and constructs (construes) it to be a 
certain way" (2011, p. 101, orig. italics). From this perspective, the language the coaches were appropriating and, ultimately, articulating publicly, allowed us to construct alternatives to the systems, approaches and beliefs that had contributed to our district's racial and socioeconomic achievement gap.

Subsequently, analyzing the discursive moves within one conversation between the four coaches can provide a window into the negotiation and development of these shared beliefs.

\section{Co-construction of a public document}

One vivid example of the development of the coaches' shared discourse could be seen when we collaborated around an upcoming presentation. During our first year of working together, Sharon, Carol, Rachel and I were asked to present to a neighboring local educational agency (LEA) about our coaching work; that LEA had just begun supporting coaches within its area schools. In preparation for our presentation, we decided to record, and ultimately share, the core beliefs about literacy that guided our work. Over breakfast at a local coffee shop, we co-constructed this document.

The excerpt below offers a window into this conversation. At the time, I was sitting in front of my laptop computer, recording what the others said and offering input. Short (.) and longer (..) pauses are noted, as are overlapping statements $(=)$; these signal moments during the conversation when we were thinking about how to formulate our thoughts and building upon each other's ideas.

Rachel: Don't type this...culturally relevant personal literacies as a bridge to - I don't know how to say this - as a bridge to (.) um (.) I don't know how to say it, as a bridge to (..)

Carol: What's the word? Power? Or to enable or to create and foster an environment for learning? Or to (..)

Laura: How about, "We strive to incorporate culturally relevant materials to master a love of" (.) because the purpose of using those materials is to get kids interested and engaged.

In the above excerpt, notice how Rachel thinks out loud, articulating her belief in "culturally relevant personal literacies." She gets stuck, however, when she tries to articulate the ultimate outcome for students. Carol jumps in, offering some possibilities. However, she frames these as questions; in doing so, she invites others to share their insights. I pick up on Carol's bid and summarize what has already been said. Next, I offer a suggested outcome, 
articulating a purpose for giving students access to culturally relevant materials. The conversation continues, offering an example of how we negotiated our beliefs around best practice literacy instruction and how we built a cohesive, collaborative statement about the student-centered goals of our work.

Rachel: Mmmm, hmmm. It's a bridge.

Carol: I just think that 'love' is, for lack of a better word, too aesthetic.

Laura: Should we say, "We strive to use culturally relevant materials to empower students to be active participants (..)

Carol: Active learners? To learn actively? To learn and think (..) What would you say, [Sharon]?

Laura: So right now, we have, "we strive to use culturally relevant materials to empower students to.." And we can always rewrite this (..)

Sharon: To interact with texts. Or, to (..) $=$

Rachel: $\quad=$ To interact with texts

Laura: To have meaningful interactions?

Rachel: With texts both on a personal and academic level? Or use personal as a bridge to academic $=$

Carol: $\quad=$ Which is our main connection to building background knowledge and all of our really best practice literacy strategies.

As the above transcript reveals, our beliefs were not fixed; they were fluid and negotiated by the group as a whole. There were explicit efforts made to ensure that each coach's voice was represented. Noticing that Sharon was characteristically quiet, Carol invited her contribution. As note taker, I frequently restated the language we had agreed upon, and clarified ("we can always rewrite this") that there was still room for revision.

Ultimately, this activity allowed us to construct and formalize our priorities as we engaged with both district and building staff; these priorities reflect the coaches' shared internally persuasive discourse (Bakhtin, 1984). Bakhtin's theory of discourse derives from the belief that language is socially constructed and that it develops in a dialogic relationship between speaker, history, perceived audience and ideology. He goes so far as to assert, "the ideological becoming of a human being, in this view, is the process of selectively assimilating the words of others" (1984, p. 340). In contrast to an 
authoritative discourse, which is "encountered with its authority already fused to it" (p. 342), the internally persuasive discourse is "half-ours and halfsomeone else's" (p. 345) It is open to be developed by the speaker, to be creatively applied to new situations. This process is evident above in the coconstructed utterances, overlaps, and questions that are posed by the coaches. Furthermore, we understood that each coach's commitment to supporting marginalized students permeated the words being shared and assimilated. Within the Lake City School District, which was struggling to meet the needs of its diverse study body, this was instrumental in allowing us to articulate our beliefs.

Our shared discourse was rooted in the belief that the status quo was insufficient. Carol expressed this during our last interview together: "I think what needs to happen in our system is HUGE. It can't just be pockets of things happening here and here and here." The fact that so many of our students of color, our English language learners and our students from lower socioeconomic backgrounds, were continuing to struggle compelled our attempts to bring about change.

A closer analysis of this excerpt, as well as many other conversations that occurred within the Literacy Coach Collaborative meetings, also reveals that the coaches prioritized beliefs and instructional activities consistent with a critical literacy stance. We believed that instruction should be built around "culturally relevant materials" that served to "empower" students to interact with texts on both "personal and academic" levels. Critical theories about literacy are described below, and an extended analysis of the coaches' shared beliefs follows.

\section{Critical theories about literacy instruction}

Critical literacy scholars argue that while texts often reflect and seek to maintain the dominant power structures, the pliable nature of language means that those texts can be "rewritten" in order to shift the existing power dynamics in favor of groups that have been disadvantaged (Morgan, 1997; Freire, 2000; Janks, 2010).

From this perspective, literacy coaches would engage with "various social, ideological, cultural and political contexts" when negotiating decisions about best practice literacy instruction and policy (Morrell, 2008, p. 5). In addition, educators working within a critical literacy framework would seek authentic instructional experiences that are driven by their students; they would 
eschew prepackaged curriculum and programs that require a one-size-fits all approach to instruction (Vasquez, 2001). Opportunities for students to read and write their "selves" (Morgan, 1997) would be prioritized, in part by valuing the resources, concerns and interests that students and their families bring into the classroom (Compton-Lily, 2004; Ladson-Billings, 2009).

\section{Critical literacy and the coaches' shared discourse}

During my last interview with Rachel, she referenced an "assumed knowledge base that we all [the lit coaches] have," one that existed as the foundation of our conversations. She not only acknowledged that shared knowledge base, but she offered a detailed description of it. Our shared discourse, Rachel contended, was comprised of "things we take for granted, like motivation, engagement and student choice and appropriate materials, welltrained teachers and resources"; these elements were presumed to be essential components of any secondary literacy program.

A review of the larger data set revealed that this "assumed knowledge base" reflected the principles of critical literacy articulated above. First, in order for literacy instruction to be engaging, culturally relevant and empowering, it must serve as a bridge between students' personal literacies and the academic literacies with which they are expected to engage at school. Students must have opportunities to have meaningful interactions with texts. Second, while providing students with choice is essential to increasing engagement, choice must be accompanied by appropriate skill instruction. As Carol stated during our final interview, "You can't just do silent reading time without doing some explicit skill instruction...".

Third, the coaches agreed that adolescents who have been identified as "struggling readers" deserve a range of intervention options taught by the most qualified reading teachers. During a LCC meeting, Rachel communicated this passionately, and Carol concurred.

\footnotetext{
Rachel: And they need one-on-one instruction by a LITERACY SPECIALIST. But that is something we need to work on. I don't know if it's getting a rant or whatever it is. We've got to have it. We've got to have it! And I feel very, very strongly about it.

Carol: I'm with you!

Rachel: And I'm going to continue to march down this line because we will not be able to help these kids unless we have something like that.
} 
Here, Rachel urges the coaches to advocate for the hiring of qualified literacy teachers ("something we need to work on"), by either yelling about it ("getting a rant") or using another tactic. Like so many districts, LCSD had historically supported reading instruction in the high schools primarily by funding the purchase of commercial reading curricula in lieu of hiring expert reading teachers or providing additional training in reading instruction. To us, this meant that our struggling readers, a disproportionate number of whom were students of color, were not getting the support that they deserved. No "one-sizefits-all" program was going to meet the needs of our diverse student body.

\section{The Power of a Shared Discourse: It Gives Us "Muscle"}

The beliefs articulated above both constructed and were constantly refined by the shared discourse that the coaches shaped collaboratively. This discourse, and the meetings in which it was developed, "gave us muscle" (Carol) as we interacted with our building staff. It also allowed us to jointly advocate for change that would support the needs of students who had been traditionally marginalized within our district.

Wenger, McDermott \& Snyder (2002) explain why shared understandings are important within the context of a community: "One of the primary tasks of a community of practice is to establish this common baseline and standardize what is well understood so that people can focus their creative energies on the more advanced issues" (p. 11). In this way, our shared understandings allowed us to advocate for continued attention to adolescent literacy at the district level. This became particularly important as we engaged more frequently with district-level policy and needed to "focus [our] creative energies" on finding ways to challenge the status quo.

\section{From shared discourse to action}

The Literacy Coach Collaborative provided a safe, fertile space where the four coaches were able to develop an authentic community of practice and where we could engage with possibilities and challenges of our coaching roles. Opportunities to co-construct coaching resources and tools, as well as to talk through challenges we faced, allowed us to develop and articulate shared beliefs about our work, beliefs that were grounded in critical theories about literacy instruction. However, in order to enact those beliefs, we needed to publicly advocate for change, both at the school and district levels. 


\section{Critically oriented leadership}

Critically oriented leaders are driven by social justice and equity goals, and they explicitly work to question and dismantle structures that stand in the way of these goals. They recognize that existing inequities are the direct, though often tacit and hidden, results of historical constructions of schooling and of the structures that guide school practices (Capper, 1998; Sirotnik \& Oakes, 1986). Capper (1998) offered a list of questions that leaders might pose if they are operating from a critically oriented perspective. When encountering a proposed change initiative, for example, they would pose questions such as: To what end is this reform being enacted? and "Who is benefitting from the situation? Whose interests are (and are not) being served by the situation? Whose knowledge/point of view is privileged?" (Capper, 1998, p. 358).

Though none of the coaches formally identified themselves as a critically oriented leader at the time, we recognized that existing programs and policies were not sufficient to support the students who were struggling within our district, and we explicitly linked these conversations with issues of race, culture, socioeconomic status and power. During one of our interviews, Carol expressed her frustration after attending a LCSD meeting about a proposed change within the district. She said, "I went for a walk [after a district meeting], and I was thinking, where are our kids of color? And our poor kids?" She articulated one of our shared beliefs: The needs of our historically marginalized students had to be articulated and prioritized. From her perspective, their needs were absent from a district-level conversation about reform that she had just attended.

Critically oriented educators can work both within the existing systems and "within the margins" (Lewison, Leland \& Harste, 2008, p. xxii) to promote equity and social justice ends, even within systems like the Lake City School District that are increasingly characterized by top-down mandates and a desire for consistency and fidelity. In Figure 1 below, I present a framework for coaches who are interested in working towards critical change within their districts.

This framework presents six approaches that the LCSD high school coaches employed in order to push for change within our schools and within the broader district context. These approaches are nonlinear and recursive, and they can occur simultaneously. This is reflected in the cyclical nature of the figure. For example, one way of advocating for increased attention to adolescent 
literacy is to recommend that available funds be used to purchase differentiated content-area texts.

As is indicated on the diagram below, these approaches also pose different levels of risk to the coaches who engage them in their daily work. For example, embedding critical literacy principles into a public document that a coach develops with like-minded colleagues is a much more discreet disruption of the status quo than is publicly questioning policies in the presence of district staff and administrators.

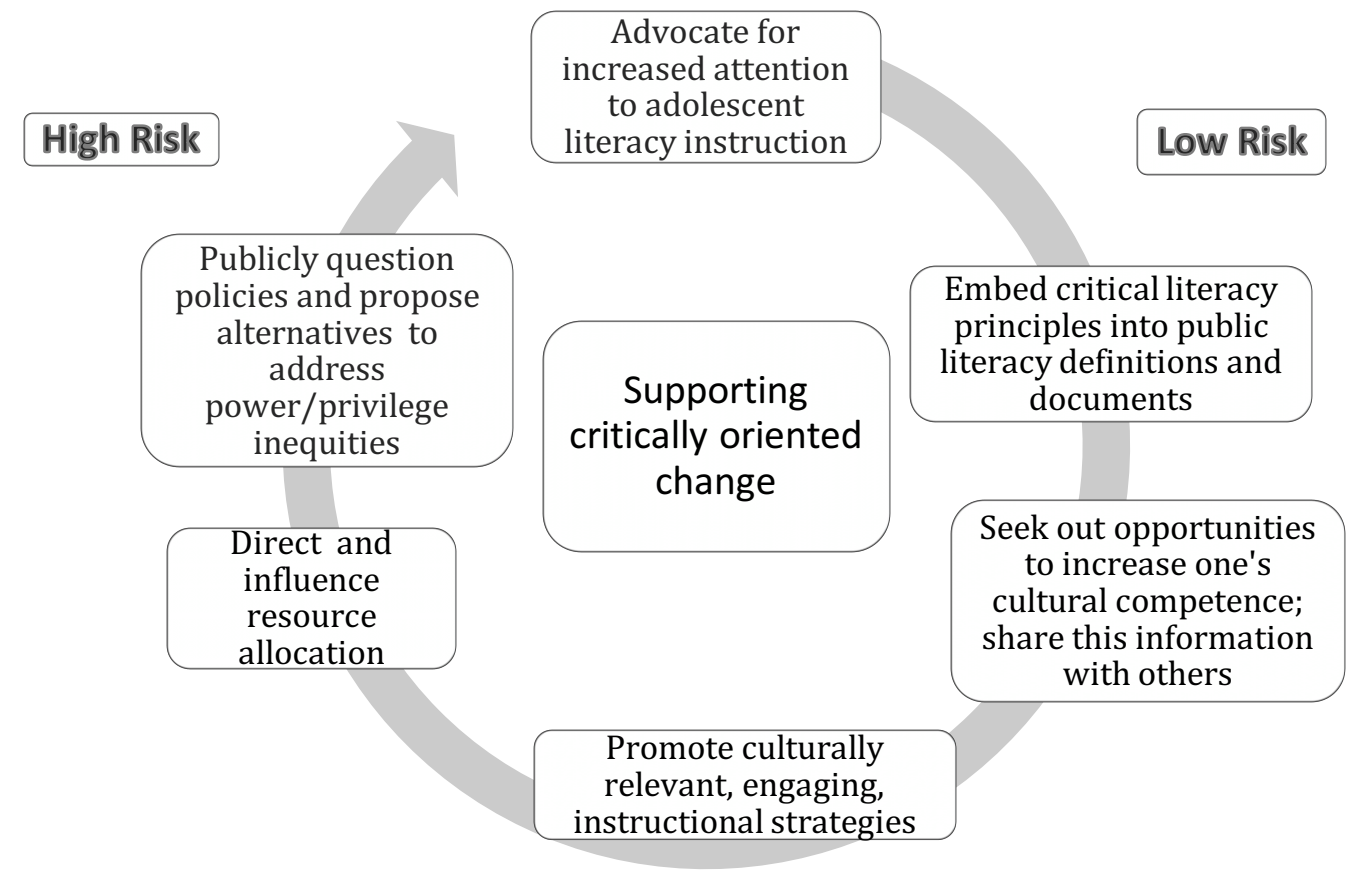

Figure 1. Critically oriented approaches to coaching role actions taken by the LSCD literacy coaches

\section{Conclusions \& Implications}

Unlike many coaches who are hired into their positions to support and enact particular policies or curricula such as Reading First (Deussen et al, 2007; Affinito, 2011), the LCSD coaches were hired to improve literacy on a broader scale. This, along with the structure of the Literacy Coach Collaborative, afforded us the opportunity to propose, negotiate and develop shared beliefs about our work. Ultimately, as we advocated for increased attention to adolescent literacy in our district, we tried to create critical spaces within the schools. The spaces valued multiple ways of knowing and encouraged the 
integration of diverse voices into the curriculum (Lewison, Leland \& Harste, 2008), recognized that race and class needed to be better understood and celebrated (Ladson-Billings, 2009), and advocated that resources be directed toward supporting the needs of our students who had been marginalized.

We encountered many obstacles along the way, and we were not always successful in our efforts. However, we knew that our collective voice, driven by our shared discourse, elevated these issues at both the school and district levels. Bean \& Carrol (2006) shared, "Coaches with whom we have worked indicate that the best form of professional development for them has been the opportunity to talk with other coaches" (p. 150). Building upon my own experiences in LCSD, I recognize the importance of giving coaches an opportunity to explore, together, the possibilities and challenges of their work. The framework for critically oriented coaching presented here can be used to initiate that conversation. As instructional coaching continues to expand, both within the United States and internationally, those who train and support coaches can create spaces for reflection, spaces that can help them answer the question, "To what end am I coaching?"

\section{References}

Affinito, S. (2011). Literacy Coaching: Negotiating Roles and Realities. Dissertation completed at University of Albany, State University of New York. UMI Number: 3489660. Retrieved from Proquest on February 9, 2012.

Aguilar, E. (2013). The Art of Coaching: Effective Strategies for School Transformation. San Francisco, CA: Wiley.

Apple, M. (2000). Official Knowledge: Democratic Education in a Conservative Age. New York, NY: Routledge.

Apple, M. (2004). Ideology and Curriculum. New York, NY: Routledge.

Apple, M. (2018). The Struggle for Democracy in Education: Lessons from Social Realities. New York, NY: Routledge.

Bakhtin, M.M. (1981). The Dialogic Imagination: Four Essays. Michael Holquist (Ed.). Trans. C. Emerson and M. Holquist. Austin, TX: University of Texas Press.

Bean, R. \& Carroll, K.E. (2006). The literacy coach as catalyst for change. In C. Cummins (Ed.), Understanding and implementing Reading First initiatives: The changing role of administrators. Newark, DE: International Reading Association. 
Blamey, K.L., Meyer, C.K. \& Walpole, S. (2008). Middle and high school literacy coaches: A national survey. Journal of Adolescent and Adult Literacy, 52(4), 310-323.

Capper, C. (1998). Critically oriented and postmodern perspectives: Sorting out the differences and applications for practice. Educational Administration Quarterly, 34(3), 354-379.

Carnegie Council for the Advancement of Adolescent Literacy. (2010). Time to Act: An Agenda for Advancing Adolescent Literacy for College and Career Success. New York, NY: Carnegie Corporation.

Cochran-Smith, M. \& Lytle, S. (1993). Inside/Outside: Teacher Research and Knowledge. New York, NY: Teachers College Press.

Compton-Lilly, C. (2004). Confronting Racism, Poverty, and Power: Classroom Strategies to Change the World. Portsmouth, NH: Heinemann.

Costa, A.L. \& Garmston, R.J. (2016). Cognitive Coaching: A Foundation for Renaissance Schools. Foxboro, MA: Christopher-Gordon.

Deussen, T., Coskie, T., Robinson, L. \& Autio, E. (2007). "Coach" can mean many things: Five categories of literacy coaches in Reading First. Issues \& Answers Report, REL, 5.

Fairclough, N. (1989). Language and Power. Essex, UK: Longman Group.

Freire, P. (2000). Pedagogy of the Oppressed: $30^{\text {th }}$ Anniversary Edition. New York, NY: Continuum International Publishing Group, Inc.

Fullan, M. (2011). Coaches as System Leaders. Educational Leadership, 69(2), 50-53.

Gee, J.P. (2011). An Introduction to Discourse Analysis: Theory and Method, $3^{\text {rd }} E d$. New York, NY: Routledge.

International Reading Association [IRA]. (2006). Standards for Middle and High School Literacy Coaches. Newark, DE: Author.

Janks, H. (2010). Literacy and Power. New York, NY: Routledge.

Ladson-Billings, G. (2009) The Dreamkeepers: Successful Teachers of African American Children. San Francisco, CA: Josey Bass.

Lewison, M., Leland, C. \& Harste, J. C. (2008). Creating Critical Classrooms: K-8 Reading and Writing with an Edge. New York, NY: Taylor \& Francis Group, LLC.

Morgan, W. (1997). Critical Literacy in the Classroom: The Art of the Possible. New York, NY: Routledge.

Morrell, E. (2008). Critical Literacy and Urban Youth: Pedagogies of Access, Dissent and Liberation. New York, NY: Taylor \& Francis. 
Mraz, M., Algozzine, B. \& Watson, P. (2008). Perceptions and Expectations of Roles and Responsibilities of Literacy Coaching. Literacy Research and Instruction, 47, 141-157.

Neufeld, B. \& Roper, D. (2003). Coaching: A strategy for developing instructional capacity-promises and practicalities. Report prepared for the Aspen Institute on Education and the Annenberg Institute for School Report.

Rogers, R. (2014). Coaching Literacy Teachers as They Design Critical Literacy Practices. Reading \& Writing Quarterly, 30, 241-261.

Saldaña, J. (2009). The Coding Manual for Qualitative Researchers. Thousand Oaks, CA: Sage Publications.

Sirotnik, K. \& Oakes, J. (1998). Critical Inquiry for School Renewal: Liberating Theory and Practice. In Authors (Eds) Critical Perspectives on the Organization and Improvement of Schools (pp. 3-93). Boston, MA: Kluwer-Nijhoff Publishing.

Sturtevant, E. (2003). The Literacy Coach: A key to improving teaching and learning in secondary schools. Alliance for Excellent Education.

Sweeney, D. (2011). Student-Centered Coaching: A Guide for K-8 Coaches and Principals. Thousand Oaks, CA: Corwin.

Vasquez, V. (2001). Constructing a Critical Curriculum with Young Children. In Comber B. and Simpson, A. (Eds.), Negotiating Critical Literacies in Classrooms (pp. 55-68). Mahwah, NJ: Lawrence Erlbaum Associates, Inc.

Weick, K. E. (2001). Making sense of the organization. Oxford: Blackwell.

Wenger, E., McDermott, R.A., Snyder, W. (2002). Cultivating Communities of Practice: A guide to managing knowledge. Boston, MA: Harvard Business School Press.

Zeni, J. (Ed.) (2001). Ethical Issues in Practitioner Research. New York, NY: Teachers College Press.

\section{Acknowledgements}

Many thanks to my wonderful coaching colleagues who agreed to participate in this study. I would also like to express gratitude to Julian Humphreys and to the anonymous reviewers who provided critical, actionable feedback. 


\section{Author Contact}

Questions about this paper can be directed to Laura M. Lang, in the Educational Leadership \& Policy Analysis Department at the University of Wisconsin-Madison: 1lang2@wisc.edu. 


\title{
Book Review
}

\section{Chestnut, B. (2017). The 9 Types of Leadership: Mastering the Art of People in the 21st Century Workplace. USA: Post Hill Press.}

\author{
Elena Khomenko \\ Toronto, Canada
}

I think the biggest benefit of using the Enneagram is that it really lets people become a better version of themselves, as opposed to just typecasting themselves.

- T. Pierce, Chief Digital Officer, The Bill and Melinda Gates Foundation, cited in Chestnut (2017)

The purpose of The 9 Types of Leadership: Mastering the Art of People in the 21st Century Workplace is to demonstrate the application of the Enneagram as a practical tool to lead and develop diverse people in a volatile, uncertain, complex, and ambiguous world (Chestnut, 2017, p. 13). Chestnut makes a case that one of the essential leadership competencies today is the art of people $-\mathrm{a}$ conscious approach to leadership based on a keen self-awareness, integration of light and shadow sides of self, and a deep understanding of others. What makes the Enneagram a credible foundation for this art is that it provides an elegant and practical way to develop emotional intelligence, arguably the most critical leadership capability of the 21 st century. The Enneagram system helps leaders recognize their patterns of thinking, feeling, and acting, shaped by previous experiences, family history, educational background, and absorbed cultural messages, about self-worth, professional accomplishments, and social success. By exposing such patterns, the Enneagram serves two purposes. First, it offers an opportunity to more consciously approach our behaviours by choosing to break patterns that do not serve us. Second, it serves as a tool for appreciation of diversity. The Enneagram system summarizes these patterns in nine archetypes, connected in a nine-star symbol. The full discussion of the philosophical, mathematical, and spiritual roots of the system is beyond the 
scope of this review. ${ }^{1}$ In its practical application to leadership development, the Enneagram system of archetypes serves as a tool to connect the understanding of personality types as a way of better relating to others, and the path to personal growth and development.

Chestnut, a licensed psychotherapist and executive coach, is a prominent authority on the modern interpretation of the Enneagram. She served as the President of the International Enneagram Association (2006 - 2009) and was a founding co-editor of the IEA journal in 2008-2009. The book under review, together with her first work (Chestnut, 2013), provides an accessible description of the Enneagram as it applies to leadership development.

After presenting a general business case for using the system, Chestnut provides a light introduction to the foundations and history of the Enneagram followed by detailed description of its nine types (and 27 subtypes) as they apply to leadership. Each chapter dedicated to an Enneagram type explains its typical personality structure. Descriptions of the type's strengths, patterns of thinking, feeling, and acting, its blind spots, specifics of its communication style, and workplace behavior are also presented. As expected, there is plenty of practical advice on how to identify one's own type and how to more effectively communicate with and manage other Enneagram types.

In my view, what makes this book different from other leadership typologies is that in its advice it follows the essence of the Enneagram theory. The Enneagram presents personality as a survival strategy that may be modified by conscious choice. It goes beyond personality typing and offers descriptions of how the high- and low-integrated personality types manifest themselves. More importantly, The 9 Types outlines the path for moving towards better integration and balance.

This map of the path to integration is what makes the Enneagram so attractive as a tool for leadership development and executive coaching. It goes beyond typology and mechanistic advice on how to manage different types better. Too often popular personality systems promote stereotypes that lead to manipulation. In The 9 Types, Chestnut presents Enneagram as the "MBTI of the $21^{\text {st }}$ century" (Chestnut, 2017, p. 11). Indeed, compared to other popular leadership assessment tools, this system provides a more nuanced description of personality types and a set of more specific and actionable recommendations to

\footnotetext{
${ }^{1}$ For a more complete review of the history and development of the Enneagram theory see Palmer (1991), Naranjo (1997), and Riso (1999).
} 
managers. Leaders can use The 9 Types to design effective plans to grow into more integrated selves and to access a broader range of options for authentic relating across levels of their organizations.

To support the business case and to demonstrate the impact of the use of the Enneagram on the growth of managerial consciousness, social capital, and performance of organizations of all types, Chestnut provides numerous stories from leaders of prominent business and non-profit organizations across industries and cultures. These vignettes illustrate practical outcomes of the recommended uses of the Enneagram. We find cases of leaders who used the system for observation and understanding of their own patterns and limitations and, as a result, started making more conscious choices in building business and relationships. Also mentioned are the examples of how leaders' self-awareness and vulnerability brought about a dramatic improvement of relationships at work. Finally, we read about applications of the Enneagram to various leadership development initiatives. One of my favourite stories is how the Enneagram developmental strategies were used as a 'more egalitarian method' to motivate managers of all levels to become more conscious in their business and leadership choices.

The 9 Types is recommended to leadership development practitioners, coaches, and managers. It provides a simple and practical framework for building emotional intelligence in leaders and growing social capital in teams that may contribute to making modern workplaces more fit for human life. The Enneagram system offers the promise of a more conscious way to live and relate to others. The 9 Types of Leadership is a great companion for anyone who works to bring conscious leadership to organizations.

\section{References}

Chestnut, B. (2013). The complete Enneagram: 27 paths to greater selfknowledge. Berkeley, CA: SWP.

Chestnut, B. (2017). The 9 types of leadership. Mastering the art of people in the $21^{\text {st }}$ century workplace. USA: Posthill Press.

Naranjo, C. (1997). Transformation through insight: Enneatypes in life. Chino Valley, AZ: Hohm Press.

Palmer, H. (1991). The Enneagram: Understanding yourself and others in your life. San Francisco, CA: HarperSanFrancisco.

Riso, D. (1999). Wisdom of the Enneagram. London, UK: Bantam. 


\title{
Book Review
}

\section{Wheatley, M. (2017). Who Do We Choose To Be?: Facing Reality, Claiming Leadership, Restoring Sanity. Oakland, CA: Berrett-Koehler Publishers}

\author{
Tamar Kagan \\ Toronto, Canada
}

I want to state up front my deep affection and appreciation for Margaret Wheatley. Wheatley's books aren't just facts and figures, they aren't simply a vision for a different world, they aren't manuals to guide action; they are pieces of art, meditations, journeys into deep places, cries for change, calls to action, yearnings for a better world. Her books are expansive, creative, generative, and deeply personal.

The title of her latest book is a mouthful - Who Do We Choose To Be?: Facing Reality, Claiming Leadership, Restoring Sanity. Every word of the title counts, representing a critical thread that is built into the structure of the book. Each chapter begins with 'what science teaches us' and then uses the three subtitles to explore the theme. Wheatley identifies two lenses that she uses throughout the book that help the reader see the current context more clearly the first is the Science of Living Systems, and the second, the Pattern of Collapse of Complex Systems.

In the opening of the book, in a section entitled Dwelling Mind, Wheatley articulates her intention regarding the layout and design of the book. There are quotes, poems and photographs taken by Wheatley interspersed between sections, all of which force you to read the book slowly. Each section has a few parts and the repetitive structure provides stability for the reader. She wants us to breathe as we read, to have space and to do all we can to not become overwhelmed. Her intentional crafting of the reading experience gave me the strong sense that she was right beside me as I read.

Wheatley does not hold back. She paints a dark picture of our world. She speaks about the current human condition, the state of our planet, and the nature of our global leadership. She doesn't mince words - our civilization is 
going through a period of disintegration and collapse, she claims. We see it in politics, in business, and in our decaying planet. Leaders have failed to see the solutions before them to build healthy and sustainable societies. Just like past civilizations that arose full of promise, hit their peak, and lost their way, so too are we following that path. There is no turning back. The markers of civilizational decline are all around us. Wheatley makes the point that "a culture focused on individual freedom can only result in narcissism, polarization, conflict, estrangement and loneliness" (p. 69). You don't need to look far to see evidence of all of these in our current culture.

Before you read the first page of the book, you have a sense of Wheatley's influences. The book is dedicated to Pema Chodron, a Buddhist nun with whom Wheatley studied and taught. The essence of the subtitle 'Facing Reality' is about deeply tuning in to what is so, not turning away, being with things as they truly are, and taking a breath. Human beings tend to reach for pleasure and avoid pain, so this is a difficult task, especially when her words ring true; however, Wheatley is clear that we must start by facing the current state of the world as it is.

After a long career in leadership and organizational development, working internationally with some of the world's most successful organizations, Wheatley no longer has faith in big system change that's sustainable and of benefit to all on a large scale. Her anger, despair and sadness are palpable; after all, this has been her life's work. But to say she's given up would miss the point; rather, she has moved her focus from global leaders to local leaders. She calls on all of us to claim leadership and do all we can to make our pockets of the world kinder, more open, more agile. She calls forth "warriors for the human spirit." The focus for these 'warriors' is to create 'islands of sanity' in the areas in which they live and work. These islands are about protecting, cultivating, and nurturing the human spirits of those around us. She asks great questions and explores what it is to be a leader in a time of collapse.

Readers will, I expect, find the book deeply distressing; but what the reader is left with, more than the pain, is the powerful experience of hearing the truth. In today's world of 'fake news,' it is extremely empowering to have someone say out loud what we can all feel is happening; and it's only from there that we can decide who we choose to be.

Margaret Wheatley is to be celebrated for her courage and for truly modeling what it is to be a warrior of the human spirit. 